\title{
Bölgeler Arası Gelişmişlik Düzeylerinin Belirlenmesi ve Karşılaştırılması: Türkiye Örneği*
}

\author{
Aydın Ünsal ${ }^{* *}$ \\ Seher Nur Sülkü ${ }^{* * *}$
}

\begin{abstract}
Öz
Bu çalışmada Türkiye'deki illerin ve bölgelerin gelişmişliği araştırılmış ve birbirleriyle kıyaslayarak incelenmiştir. İllerin gelişmişlik düzeylerini etkileyen sosyo-ekonomik göstergeler Kalkınma Bakanlığı'ndan elde edilmiştir. Temel bileşenlerden yararlanılarak faktör analizi yapılmış ve on temel faktör bulunmuştur. Bu faktörlere dayanılarak iller için gelişmişlik endeksleri oluşturulmuştur ve altı gelişmişlik düzeyi tanımlanmıştır: İleri(1.), Yüksek(2.), Yükseğe Yakın (3.), Ortalamaya Yakın (4.), Düşüğe Yakın (5.) ve Düşük (6.). İstanbul'un gelişmişlik endeksi en yakın takipçisi Ankara’nın iki katıdır ve İstanbul tek başına 1. gelişmişlik düzeyini oluşturmaktadır. Bölgelerin gelişmişlik düzeyleri incelendiğinde ortalamada yükseğe yakın performans gösteren bölgeler: Marmara, Batı Anadolu, Ege ve Akdeniz bölgeleridir. Düşük seviyede performans gösteren bölgeler ise Doğu Anadolu ve Güneydoğu Anadolu Bölgeleridir. Türkiye, ortalamada yaklaşık 3 gelişmişlik düzeyi ile "Yükseğe yakın" gelişmişlik grubundadır. İllerin \%63'ünün 4. - 6. gelişmişlik seviyelerinde yer almalarına rağmen Türkiye'nin gelişmişlik seviyesinin 3. kademe çıkmasının nedeni yüksek gelişmişlik seviyelerinde olan bölgelerin yoğun nüfus bulundurmalıdır. Ancak gelişmişlik düzeyi yüksek bu bölgelerin temel sorunu istihdamdir.
\end{abstract}

\section{Anahtar Kelimeler}

Kalkınma, bölgesel gelişmişlik düzeyi, temel bileşenler analizi, faktör analizi, Türkiye.

Geliş Tarihi: 20 Eylül 2017 - Kabul Tarihi: 30 Mayıs 2019

Bu makaleyi şu şekilde kaynak gösterebilirsiniz:

Ünsal, Aydın ve Seher Nur Sülkü (2020). "Bölgeler Arası Gelişmişlik Düzeylerinin Belirlenmesi ve Karşılaştırılması: Türkiye Örneği”. bilig - Türk Dünyası Sosyal Bilimler Dergisi 95: 177-209.

** Prof. Dr., Ankara Hacı Bayram Veli Üniversitesi, İİBF, Ekonometri Bölümü - Ankara/Türkiye ORCID ID: 0000-0002-7922-1329

aydin.unsal@hbv.edu.tr

*** Prof. Dr., Ankara Hacı Bayram Veli Üniversitesi, İIBB, Ekonometri Bölümü - Ankara/Türkiye ORCID ID: 0000-0002-4938-4565

seher.sulku@hbv.edu.tr 


\section{Giriş}

Bölgeler ortak kültür, gelişmişlik düzeyi ve siyasi kuruluşları içeren ve ortak coğrafyaya ait olan topluluklardır. Bölgelerin uluslararası siyasetteki rolü, Soğuk Savaşın bitmesiyle iki kutuplu dünya düzeninin sona ermesi üzerine önem kazanmaya başlamıştır (Fukuyama 2000).

Dünyada, bölgelerarası gelişmişlik farkları ülkeleri gelişmiş, gelişmekte olan ve az gelişmiş kategorilerine ayırmıştır (Nielsen 2011: 8). Ülkelerarası gelişmişlik farklarının yanı sıra ülke içindeki bölgelerin gelişmişlik farkları ülke içindeki huzuru tehdit eden önemli bir sorun olarak ön plana çıkmıştır. Dolayısıyla hem dünya çapında hem de ulusal ölçekte bölgelerarası gelişmişlik farkını en aza indirmek amacıyla devletler önemli çalışmalar gerçekleştirmektedir (Karg1 2009: 20, TODAİE 2009: 3-4).

Ekonomik büyümenin ekonomik kalkınmaya dönüşebilmesi bölgeler arasında gelir dağılımındaki çarpıklıkların giderilmesi ve refahın tüm ülkeye yayılması ile mümkündür (Çaşkurlu 2014: 43-44). Türkiye Cumhuriyeti’nin önemli kalkınma yöntemlerinden biri, bölgelerarası gelir dağılımının iyileştirilmesi yönündeki politikalardır ve bu politikalar bölgesel kalkınma modellerinin önemini artırmaktadır (TODAİE 2009). İllerin gelişmişlik durumlarının ve olası gelişme potansiyellerinin incelenmesi, izlenecek bölgesel büyüme politikalarına yön vererek bölgede yaşayan nüfusun yaşam kalitesinin ve refah düzeyinin yükseltilebilmesi için çok önemlidir. $\mathrm{Bu}$ çalışmanın amacı Türkiye'deki illerin ve bölgelerin gelişmişliğini analiz etmek ve birbirleriyle kıyaslamaktır.

Literatürde, Türkiye'deki illerin ve bölgelerin sosyo-ekonomik gelişmişlik sıralamasını belli yıllar için inceleyen az sayıda çalışma bulunmaktadır (Dinçer vd. 1996, Dağ 2000, Dinçer vd. 2003, Ünsal ve Özgür 2004, Atan vd. 2004, Kalkınma Bakanlığı 2013, Gül ve Çevik 2015). Üstelik, gelişmişlik araştırmasını sadece bir sene için yapmak yeterli değildir; sürekli olarak endeks yinelenmeli ve yıldan yıla illerin ve bölgelerin performanslarındaki gelişim takip edilmelidir. Bu nedenle makalemizde en güncel veri seti kullanılarak Türkiye için gelişmişlik analizi yapılmıştır.

Gelişmişliği kıyaslamada standart bir kıyaslama ölçüsü yoktur. Gelişmişlik kıyaslamalarında gelir önemli bir gösterge olsa da bu gösterge tek başına yeterli değildir. Gelir, istihdam düzeyi gibi üretime ait nicel değişkenlerin 
yanı sıra özel hayata saygı, mutluluk, yaşam memnuniyeti gibi nitel ve sübjektif değişkenler de yaşam kalitesini ve dolayısıyla gelişmişlik düzeyini belirlemede önemli göstergelerdir (Nielsen 2011: 5-7). Dolayısıyla araştırmamızda geniş yelpazede birçok sosyo-ekonomik göstergenin kapsanmasına özen gösterilmiştir. Analizlerimizde, Türkiye'deki 81 ilin gelişmişlik düzeylerini etkiledikleri düşünülen gelir, eğitim, sağlık, istihdam, rekabetçilik, erişilebilirlik (ulaşım), yaşam kalitesi, demografik değişkenler ve mali göstergelerden 58 değişken değerlendirilmiştir. Güncel veri seti Kalkınma Bakanlığı'ndan elde edilmiştir.

Bu makalenin düzeni şu şekildedir: İkinci Bölüm'de illerin gelişmişliğini etkileyen faktörler belirlenmiştir. $\mathrm{Bu}$ amaçla çok değişkenli istatistik yöntemlerinden olan temel bileşenlerden yararlanılarak faktör analizi uygulanmıştır. Temel bileşenler analizi ve faktör analizi yöntemleri, birbirleri ile yüksek korelasyona sahip çok sayıdaki değişkeni birbirleriyle ilişkisiz az sayıda değişkene indirgemek üzere geliştirilmiştir (Chatfield ve Collins 1980). Analimiz sonucunda 58 değişken 10 faktöre indirgenmiştir. Elde edilen faktörlerin varyans açıklama yüzdeleri incelenerek, toplam varyansın \%84,26'sının önemli faktörlerce açıklanabildiği ortaya konulmuştur. Sonrasında, faktörlere yükleme yapan değişkenler incelenerek, değişkenler arasındaki ortak nokta belirlenmiş ve bu on faktör isimlendirilmiştir.

Çalışmanın Ü̧̧üncü Bölümünnde faktörlerin toplam varyansı açılamadaki payları dikkate alınarak iller için insanigelişmişlikendeksleri oluşturulmuştur. İllerin gelişmişlik endeksleri analiz edilerek altı tane gelişmişlik düzeyi belirlenmiştir: İleri(1.), Yüksek(2.), Yükseğe Yakın (3.), Ortalamaya Yakın (4.), Düşüğe Yakın (5.) ve Düşük (6.). Bulgularımıza göre sadece İstanbul ileri (1.) gelişmişlik düzeyini oluşturmaktadır ve bu düzey diğer illerin oldukları seviyelerden çok yüksektir.

İllerin gelişmişlik düzeylerinden sonra bölgelerin gelişmişlik düzeyleri Avrupa Birliği ile uyum çerçevesinde oluşturulan NUTS-1 (Nomenclature of Territorial Units for Statistics (NUTS), İstatistiki Bölge Birimleri Sınıflandırması (İBBS)) sınıflandırmasına göre analiz edilmiştir (Öztürk 2009: 19).

Çalışmamızda son olarak bölgelerin gelişmişlik skorlarından faydalanılarak Türkiye’nin nüfusa göre ağırlıklandırılmış ortalama gelişmişlik düzeyi 
hesaplanmıştır ve bu değer yaklaşık olarak 3 bulunmuştur. Bu durumda Türkiye, ortalamada "Yükseğe yakın” gelişmişlik grubundadır. İllerin yaklaşık \%63'ünün daha düşük gelişmişlik seviyelerinde yer almalarına rağmen Türkiye’nin gelişmişlik seviyesinin 3. kademe çıkmasının nedeni yüksek gelişmişlik seviyelerinde olan bölgelerin yoğun nüfus bulundurmalarıdır.

Makalenin bulguları hakkındaki tartışmaya Sonuç Bölümü'nde yer verilmiştir. Ekler'de, betimleyici istatistikler ve faktör analizinde kullanılan dönüştürülmüş yük matrisi bulunmaktadır.

\section{Faktör Analizi ve Temel Bileşenler Analizi Uygulaması}

Makalede, illerin kalkınmışlık düzeylerini etkileyeceği düşünülen fazla sayıda ve birbirleriyle ilişkili değişken eşanlı değerlendirileceği için en uygun yöntem faktör analizidir. Faktör analizinde faktörleri belirlemenin birçok yöntemi vardır, temel bileşenler yöntemi bunların en temelidir. Faktör analizi ve temel bileşenler analizi yöntemleri, çok sayıdaki birbirleri ile ilişkili değişkenlerden birbirleriyle ilişkisiz ve kavramsal olarak anlamlı az sayıda değişkenlerin (faktörlerin) elde edilmesi amacıyla kullanılmaktadır (Bartholomew 1984, Flury 1998, Johnson ve Wichern 2007).

Bu yöntemler literatürde çok iyi bilinen ve sıklıkla uygulanan yöntemlerdir (Cooper 1983, Tipping ve Bishop 1999, Tatlıdil 2002, Atan vd. 2004, Ünsal ve Özgür 2004, Benko vd. 2009, Kalkınma Bakanlığı 2013). Dolayısıyla, bu bölümde direk olarak yöntemlerin çalışmaya nasıl uygulanıldığına yer verilmiştir.

Araştırmamızda, literatür takip edilerek 81 ilin her biri için gelişmişlik düzeylerini etkileyen, gelir, eğitim, sağlık, istihdam, rekabetçilik, erişilebilirlik, ulaşım, yaşam kalitesi, demografik değişkenler ve mali göstergelerden 58 değişken değerlendirilmiştir. Bu değişkenler Tablo 1'de sıralanmıştır. Güncel veri seti Kalkınma Bakanlığı’ndan elde edilmiştir (Kalkınma Bakanlığı, www.kalkinma.gov.tr/Pages/EkonomikSosyalGöstergeler.aspx, Erişim Tarihi: 20.05.2016). 
Tablo 1. Değiskenler

\begin{tabular}{|c|c|c|c|}
\hline No & Değişken Açıklaması & No & Değişken Açıklaması \\
\hline V1 & İşsizlik Oranı & V30 & Nüfus Yoğunluğu \\
\hline V2 & İşgücüne Katılma Oranı & V31 & Yaşa Özel Doğurganlık Oranı (15-49 Yas) \\
\hline V3 & $\begin{array}{l}\text { Çalışma Çağındaki Nüfusun ( } 15 \\
\text { - } 64 \text { Yaş Arası) Toplam Nüfus } \\
\text { İçerisindeki Oranı }\end{array}$ & V32 & Genç Bağımlı Nüfus Oranı (0-14 Yas) \\
\hline V4 & $\begin{array}{l}\text { İmalat Sanayi İstihdamının } \\
\text { Sigortalı İstihdam İçinde Oranı }\end{array}$ & V33 & Net Göç Hızı \\
\hline V5 & $\begin{array}{l}\text { Sosyal Güvenlik Kapsamındaki } \\
\text { Aktif Çalışanların Nüfusa Oranı }\end{array}$ & V34 & Şehirleşme Oranı \\
\hline V6 & Ortalama Günlük Kazanç & V35 & Okuryazar Nüfus Oranı \\
\hline V7 & $\begin{array}{l}\text { Ortalama Günlük Kazanç - Ka- } \\
\text { dın }\end{array}$ & V36 & $\begin{array}{l}\text { Okur-Yazar Kadın Nüfusun Toplam Ka- } \\
\text { dın Nüfusa Oranı }\end{array}$ \\
\hline V8 & İstihdam Oranı & V37 & Genel Ortaöğretim Net Okullaşma Oranı \\
\hline V9 & $\begin{array}{l}\text { İl İhracatının Türkiye İçindeki } \\
\text { Payı }\end{array}$ & V38 & $\begin{array}{l}\text { Mesleki Ve Teknik Liseler Okullaşma } \\
\text { Oranı }\end{array}$ \\
\hline V10 & Kişi-başına İhracat & V39 & YGS İl Ortalama Puanları \\
\hline V11 & $\begin{array}{l}\text { İmalat Sanayi İşyerlerinin } \\
\text { Türkiye İçindeki Payı }\end{array}$ & V40 & $\begin{array}{l}\text { Yüksek Okul Veya Fakülte Mezunu Nüfu- } \\
\text { sun }+22 \text { Yas Nüfusa Oranı }\end{array}$ \\
\hline V12 & $\begin{array}{l}\text { İmalat Sanayi Kayıtlı İşyeri Ora- } \\
\text { nı }\end{array}$ & V41 & Hastane Yatak Sayısı \\
\hline V13 & $\begin{array}{l}\text { Kişi-başına İmalat Sanayi Elekt- } \\
\text { rik Tüketimi }\end{array}$ & $\mathrm{V} 42$ & Hekim Sayısı \\
\hline V14 & $\begin{array}{l}\text { Organize Sanayi Bölgesindeki } \\
\text { Üretim yapılan Parsellerin Tür- } \\
\text { kiye İçindeki Payı }\end{array}$ & V43 & Diş hekimi Sayısı \\
\hline V15 & $\begin{array}{l}\text { Küçük Sanayi Sitesi İşyeri } \\
\text { Sayısının Türkiye İçindeki Payı }\end{array}$ & V44 & Eczane Sayısı \\
\hline V16 & $\begin{array}{l}\text { Yeni Kurulan Şirketlerin Toplam } \\
\text { Sermayesinin Türkiye İçindeki } \\
\text { Payı }\end{array}$ & V45 & Yeşilkart Sahibi Nüfusun İl İçindeki Payı \\
\hline V17 & $\begin{array}{l}\text { Onbin Kişiye Düşen Yabancı } \\
\text { Sermayeli Şirket Sayısı }\end{array}$ & V46 & $\begin{array}{l}\text { Kırsal Kesim Asfalt-Beton Koy Yolu Ora- } \\
\text { nı }\end{array}$ \\
\hline
\end{tabular}




\begin{tabular}{|c|c|c|c|}
\hline V18 & $\begin{array}{l}\text { Yüzbin Kişiye Düşen Marka Baş- } \\
\text { vuru Sayısı }\end{array}$ & V47 & $\begin{array}{l}\text { Havayolu Ulaştırma İçhat Yolcu Sayısının } \\
\text { Türkiye İçindeki Payı }\end{array}$ \\
\hline V19 & $\begin{array}{l}\text { Yüzbin Kişiye Düşen Patent Baş- } \\
\text { vuru Sayısı }\end{array}$ & V48 & Hane başına Geniş bant Abone Sayısı \\
\hline V20 & $\begin{array}{l}\text { Yüksek Lisans Ve Doktora Sahibi } \\
\text { Nüfusun }+30 \text { Yas Nüfusa Oranı }\end{array}$ & V49 & Kişi-başına düşen GSM Abone Sayısı \\
\hline V21 & $\begin{array}{l}\text { Kırsal Nüfus Başına Tarımsal } \\
\text { Üretim Değeri }\end{array}$ & V50 & $\begin{array}{l}\text { Bin Kişi-başına düşen AVM Brüt Kirala- } \\
\text { nabilir Alan Oranı (Nüfus 2010) }\end{array}$ \\
\hline V22 & $\begin{array}{l}\text { Turizm Yatırım-İşletme Ve Bele- } \\
\text { diye Belgeli Yatak Sayısının Tür- } \\
\text { kiye İçindeki Payı }\end{array}$ & V51 & $\begin{array}{l}\text { Kanalizasyon Şebekesi İle Hizmet Verilen } \\
\text { Belediye Nüfusunun Oranı }\end{array}$ \\
\hline V23 & $\begin{array}{l}\text { İl Banka Kredilerinin Türkiye } \\
\text { İçindeki Payı }\end{array}$ & V52 & $\begin{array}{l}\text { Kişi-başına Mesken Elektrik Tüketimi - } \\
\text { MWH }\end{array}$ \\
\hline V24 & $\begin{array}{l}\text { İldeki Tasarruf Mevduatının } \\
\text { Türkiye İçindeki Payı }\end{array}$ & V53 & $\begin{array}{l}\text { Onbin Kişiye Düşen Özel Otomobil Sa- } \\
\text { yısı }\end{array}$ \\
\hline V25 & $\begin{array}{l}\text { Kişi-başına Banka Mevduatı Tu- } \\
\text { tarı }\end{array}$ & V54 & Kükürtdioksit Ortalama Değeri \\
\hline V26 & $\begin{array}{l}\text { İnternet Bankacılığında Aktif } \\
\text { Bireysel Müşteri Sayısı }\end{array}$ & V55 & $\begin{array}{l}\text { Partiküler Madde (Duman) Ortalama } \\
\text { Değeri }\end{array}$ \\
\hline V27 & $\begin{array}{l}\text { İnternet Bankacılığında Aktif } \\
\text { Kurumsal Müşsteri Sayısı }\end{array}$ & V56 & $\begin{array}{l}\text { Sosyal Güvenlik Kapsamı Dışında Kalan } \\
\text { Nüfus Oranı }\end{array}$ \\
\hline V28 & Kişi-başına Bütçe Gelirleri & V57 & $\begin{array}{l}\text { Yüzbin Kişi-başı Ceza İnfaz Kurumuna } \\
\text { Giren Hükümlü Oranı }\end{array}$ \\
\hline V29 & $\begin{array}{l}\text { İl Vergi Gelirlerinin Türkiye } \\
\text { İçindeki Payı }\end{array}$ & V58 & Yüzbin Kişi-başına İntihar Oranı \\
\hline
\end{tabular}

Bu 58 değişken için betimleyici istatistikler Ek Tablo 1'de yer almaktadır. Değişkenlerin ortalamaları, standart sapma değerleri ve ölçü birimleri incelendiğinde birbirinden farklı oldukları görülmüştür. Bu sebeple faktör analizi uygulanırken standartlaştırılmış değişkenlere ilişkin korelasyon matrisi kullanılmıştır. ${ }^{1}$ Verilerin, faktör analizi için uygunluğu Barlett Küresellik testi ve Kaiser-Meyer-Olkin (KMO) ölçütü ile incelenmiştir. ${ }^{2}$ Barlett testinin boş hipotezinin, $H_{0}$ :Korelasyon matriksi birim matrikse eşittir, \%1 önem derecesinde ret edilmesi (8486,39, $p=0.00<\alpha=0.01$ ) ve KMO örneklem ölçütünün \%78.1 değeri ile \%60'dan yüksek çıkması verinin faktör analizine uygun olduğunu göstermiştir. 
Faktör kümeleri oluşturulurken temel bileşenler analizi ile özdeğeri 1'den büyük anlamlı 10 faktör tespit edilmiştir. Tablo 2'de görüldügü üzere bu faktörler toplam varyansın \%84.24’ünü açıklamaktadır.

Tablo 2. Faktörlerin Özdeğerleri ve Toplam Açıklanan Varyans

\begin{tabular}{|c|c|c|c|c|c|c|}
\hline \multirow[b]{2}{*}{ Bileşen } & \multicolumn{3}{|c|}{ Başlangıç Ōzdeḡerleri } & \multicolumn{3}{|c|}{ Rotasyon Sonrası Yükler } \\
\hline & Özdeğer & Varyans & Kümülatif Varyans & Özdeğer & Varyans & Kümülatif Varyans \\
\hline 1 & 22,73 & 39,20 & 39,20 & 8,72 & 15,04 & 15,04 \\
\hline 2 & 10,15 & 17,51 & 56,70 & 5,37 & 9,25 & 24,30 \\
\hline 3 & 3,43 & 5,91 & 62,62 & 5,27 & 9,08 & 33,38 \\
\hline 4 & 2,92 & 5,04 & 67,65 & 5,07 & 8,75 & 42,12 \\
\hline 5 & 2,41 & 4,16 & 71,81 & 4,94 & 8,52 & 50,64 \\
\hline 6 & 2,18 & 3,76 & 75,58 & 4,35 & 7,50 & 58,14 \\
\hline 7 & 1,53 & 2,63 & 78,21 & 4,27 & 7,36 & 65,50 \\
\hline 8 & 1,41 & 2,44 & 80,65 & 3,95 & 6,80 & 72,30 \\
\hline 9 & 1,08 & 1,85 & 82,50 & 3,59 & 6,19 & 78,49 \\
\hline 10 & 1,02 & 1,75 & 84,26 & 3,34 & 5,77 & 84,26 \\
\hline 11 & 0,90 & 1,55 & 85,81 & & & \\
\hline 12 & 0,82 & 1,42 & 87,23 & & & \\
\hline 13 & 0,74 & 1,28 & 88,51 & & & \\
\hline 14 & 0,63 & 1,09 & 89,59 & & & \\
\hline 15 & 0,57 & 0,98 & 90,57 & & & \\
\hline 16 & 0,54 & 0,93 & 91,50 & & & \\
\hline 17 & 0,51 & 0,87 & 92,37 & & & \\
\hline 18 & 0,48 & 0,82 & 93,19 & & & \\
\hline 19 & 0,41 & 0,71 & 93,90 & & & \\
\hline 20 & 0,40 & 0,69 & 94,59 & & & \\
\hline ... & & & & & & \\
\hline 58 & 0.00 & 0.00 & 100.00 & & & \\
\hline
\end{tabular}

Kaynak: Kendi hesaplamalarımız.

Toplamda açıklanan varyansı değiştirmeden daha okunabilir hale getirmek ve daha uygun bir faktör yapısı elde etmek için doğrusal bir rotasyon olan equamax yöntemi uygulanmışır. ${ }^{3}$ Rotasyon sonrası faktörlerin özdeğerleri ile varyans ve kümülatif varyansları da Tablo 2 'de yer almaktadır. Rotasyon öncesinde birinci faktör varyansın yaklaşık \%39'unu açıklamaktadır. Fakat rotasyon ile faktörlerin göreli önemi eşitlenmiştir ve böylece ilk faktörün katkısı \%15.04'e düşmüştür.

Sonrasında, önemli olduğu tespit edilen bu 10 faktöre yükleme yapan değişkenler incelenmiş ve değişkenler arasındaki ortak nokta belirlenerek faktörler adlandırılmıştır. Buna göre faktörlerimizin isimleri sırasıyla: 1. Faktör "Sanayi ve Banka Mevduat Hacmi", 2. Faktör "İstihdam", 3. Faktör "Sağlık ve Yüksek Öğrenim”, 4. Faktör "Üretim”, 5. Faktör "Kırsal Yaşam ve Okuryazarlık", 6. Faktör "Genç Nüfus ve Psikoloji", 7. Faktör "İşletmecilik", 8. Faktör "Kazanç", 9. Faktör "GSM Aboneliği” ve 10. Faktör "Çevre"dir. 
Faktörleri adlandırırken, faktörlere yükleme yapan değişkenler arasındaki ortak noktalar göz önüne alınmıştır. Faktör isimlerinin nasıl verildiğinin anlaşılması için örnek olarak 1.Faktörün nasıl isimlendirildiğini açıklayalım. Ek Tablo 2 Dönüştürülmüş Yük Matrisi’ nde görüldüğü üzere 1. Faktörün en çok ilişki içinde olduğu değişkenler ilişkinin güçlülüğüne göre sıralandığında şunlardır: V14 (İl İhracatının Türkiye İçindeki Payı), V23 (İl Banka Kredilerinin Türkiye İçindeki Payı), V30 (Nüfus Yoğunluğu), V24 (İldeki Tasarruf Mevduatının Türkiye İçindeki Payı), V9 (İl İhracatının Türkiye İçindeki Payı),V11 (İmalat Sanayi İşyerlerinin Türkiye İçindeki Payı), V16 (Yeni Kurulan şirketlerin Toplam Sermayesinin Türkiye İçindeki Payı), V29 (İl Vergi Gelirlerinin Türkiye İçindeki Payı), V47(Havayolu Ulaştırma İçhat Yolcu Sayısının Türkiye İçindeki Payı), V18 (Yüzbin Kisiye Düşen Marka Başvuru Sayısı) ve V25 (Kişi-başına Banka Mevduatı Tutarı). Faktör 1'in bu değişkenlerle yüksek korelasyon içinde olduğu görüldüğü için 1. Faktörün adı "Sanayi ve Banka Mevduat Hacmi” olarak verilmiştir. ${ }^{4}$

\section{Faktör skorları}

Analizimizin devamında faktör yükleme matrisinden faydalanarak her il için her bir faktör altındaki faktör skorları elde edilmiştir ve Tablo 3 'te sunulmuştur. ${ }^{5}$

1. faktör "Sanayi ve Banka Mevduat Hacmi" altında illerin faktör skor sıralamaları incelendiğinde birinci sırada yer alan İstanbul'un skoru 8,49'tur ve onu takip eden Ankarảnın skoru sadece 0,82'dir. İstanbul, sanayi ve banka mevduat hacminde bütün illerin açık ara önünde yer almaktadır.

İstihdamda ise birinci sırada Rize bulunmaktadır ve bunu Artvin, Gümüşhane takip etmektedir; buna karşın İstanbul 45., İzmir 53. ve Ankara 66. sırada yer almıştır. Bu durum şu şekilde açıklanabilir, ülkemizde küçük iller cazibe merkezi olan İstanbul gibi büyük şehirlere göç vermektedir. Dolayısıyla işsizlik göç alan illerde yoğunlaşmaktadır. Rize ve Artvin ise gelişmemiş işgücü piyasaları nedeniyle düşük işsizlik oranına sahiptir. Göç almayan illerimizin (Siirt, Batman, Diyarbakır gibi) istihdam faktöründeki düşük performansları ise bu illerdeki iş piyasasının etkinsizliğini ortaya koymaktadır. 
Tablo 3. Faktör Skorları

\begin{tabular}{|c|c|c|c|c|c|c|c|c|c|c|c|c|c|c|}
\hline \multicolumn{3}{|c|}{$\begin{array}{l}\text { SANAYI VE BANKA } \\
\text { MEVDUAT HACMI }\end{array}$} & \multicolumn{3}{|c|}{ İSTIHDAM } & \multicolumn{3}{|c|}{$\begin{array}{c}\text { SAĞLIK VE YÜKSEK } \\
\text { ÖĞRENIM }\end{array}$} & \multicolumn{3}{|c|}{ ÜRETIM } & \multicolumn{3}{|c|}{$\begin{array}{c}\text { KIRSAL YAŞAM } \\
\text { VE } \\
\text { OKURYAZARLIK }\end{array}$} \\
\hline SIRA & íl & SKOR & SIRA & í & SKOR & SIRA & iL & SKOR & SIRA & iL & SKOR & SIRA & í & SKOR \\
\hline 1 & ISTANBUL & 8,49 & 1 & RIZE & 2,21 & 1 & ANKARA & 4,56 & 1 & KOCAELI & 4,56 & 1 & BILECIK & 2,65 \\
\hline 2 & ANKARA & 0,82 & 2 & ARTVIN & 2,10 & 2 & ISPARTA & 2,41 & 2 & BURSA & 3,16 & 2 & ANKARA & 2,55 \\
\hline 3 & BARTIN & 0,58 & 3 & GÜMÜŞHANE & 1,84 & 3 & ELAZIĞ & 2,10 & 3 & GAZIANTEP & 2,35 & 3 & ÇANAKKALE & 1,83 \\
\hline 4 & ÇANKIRI & 0,40 & 4 & GIRESUN & 1,76 & 4 & IZMIR & 1,85 & 4 & MANISA & 2,32 & 4 & BOLU & 1,50 \\
\hline 5 & TOKAT & 0,29 & 5 & TRABZON & 1,41 & 5 & BOLU & 1,80 & 5 & İZMIR & 1,82 & 5 & AMASYA & 1,31 \\
\hline & $\ldots$ & & & $\ldots$ & & & $\ldots$ & & & $\ldots$ & & & $\cdots$ & \\
\hline & $\ldots$ & & & $\ldots$ & & & $\ldots$ & & & $\ldots$ & & & $\ldots$ & \\
\hline & $\cdots$ & & & $\ldots$ & & & $\ldots$ & & & $\ldots$ & & & $\ldots$ & \\
\hline 77 & MERSIN & $-0,54$ & 77 & SIIRT & $-1,77$ & 77 & KOCAELİ & $-1,04$ & 77 & ARDAHAN & $-1,11$ & 77 & MALATYA & $-1,84$ \\
\hline 78 & MUĞLA & $-0,57$ & 78 & BATMAN & $-1,79$ & 78 & NIĞDE & $-1,06$ & 78 & YOZGAT & $-1,18$ & 78 & ELAZIĞ & $-1,88$ \\
\hline 79 & ESKİŞEHIR & $-0,64$ & 79 & GAZİANTEP & $-1,85$ & 79 & SSANLIURFA & $-1,21$ & 79 & TUNCELİ & $-1,21$ & 79 & TUNCELI & $-1,92$ \\
\hline 80 & KOCAELİ & $-1,16$ & 80 & ŞANLIURFA & $-2,09$ & 80 & MUȘ & $-1,39$ & 80 & ISPARTA & $-1,29$ & 80 & ORDU & $-1,99$ \\
\hline 81 & ANTALYA & $-1,17$ & 81 & DIYARBAKIR & -2.39 & 81 & BILECIK & $-1,88$ & 81 & KIRSEHIR & -1.74 & 81 & TRABZON & -2.01 \\
\hline
\end{tabular}

Tablo 3. (Devam ediyor) Faktör Skorları

\begin{tabular}{|c|c|c|c|c|c|c|c|c|c|c|c|c|c|c|}
\hline \multicolumn{3}{|c|}{$\begin{array}{l}\text { GENÇ NÜFUS VE } \\
\text { PSİKOLOJI }\end{array}$} & \multicolumn{4}{|c|}{ İȘLETMECİLİK } & \multicolumn{2}{|c|}{ KAZANÇ } & \multicolumn{3}{|c|}{ GSM ABONELİĞİ } & \multicolumn{3}{|c|}{ ÇEVRE } \\
\hline SIRA & İL & SKOR & SIRA & İL & SKOR & SIRA & İL & SKOR & SIRA & íl & SKOR & SIRA & íL & SKOR \\
\hline 1 & TUNCELI & 4,83 & 1 & ANTALYA & 5,99 & 1 & GAZIANTEP & 2,20 & 1 & KOCAELİ & 2,69 & 1 & YALOVA & 1,14 \\
\hline 2 & KARABÜK & 1,67 & $\begin{array}{l}2 \\
3\end{array}$ & MUĞLA & 4,29 & 2 & DENİZLİ & 2,09 & 2 & KIRŞEHIR & 2,55 & 2 & ADANA & 1,14 \\
\hline 3 & AYDIN & 1,67 & 4 & $\begin{array}{l}\text { AYDIN } \\
\text { ISTANBUL }\end{array}$ & 1,08 & 3 & UŞAK & 1,80 & 3 & ISPARTA & 2,18 & 3 & İZMiR & 1,12 \\
\hline $\begin{array}{l}4 \\
5\end{array}$ & ZONGULDAK & 1,58 & 5 & İZMIR & 0,92 & 5 & OSMANIYE & 1,58 & 5 & ARTVIN & 1,99 & 5 & ANKARA & 1,10 \\
\hline
\end{tabular}

\begin{tabular}{|c|c|c|c|c|c|c|c|c|c|c|c|c|c|c|}
\hline 77 & BAYBURT & $-1,37$ & & & & 77 & BİTLİs & $-1,75$ & 77 & AKSARAY & $-1,51$ & 77 & MUŞ & $-1,18$ \\
\hline 78 & KONYA & $-1,43$ & 77 & TOKAT & $-0,90$ & 78 & MUŞ & $-1,87$ & 78 & TOKAT & $-1,83$ & 78 & KARABÜK & $-1,23$ \\
\hline 79 & YOZGAT & $-1,74$ & 78 & SIVAS & $-0,91$ & 79 & AĞRI & $-2,07$ & 79 & MANISA & $-1,89$ & 79 & BOLU & $-1,40$ \\
\hline 80 & ŞIRNAK & $-1,89$ & 80 & ÇANKIRI & $-1,16$ & 80 & ANKARA & $-2,36$ & 80 & AĞRI & $-2,41$ & 80 & TEKİRDAĞ & $-2,54$ \\
\hline 81 & Kilis & -1.97 & 81 & KIRIKKALE & -1.37 & 81 & KOCAELI & $-3,21$ & 81 & KARS & -2.67 & 81 & HAKKARI & -6.07 \\
\hline
\end{tabular}

Kaynak: Kendi hesaplamalarımız.

Sağlık ve Yüksek Öğretim faktöründe ise birinci sırada olan Ankara’nın skoru 4,56 ve sonuncu olan Bilecik'in skoru -1.88'dir. Çevre faktöründe en yüksek skorlu il Yalova olurken bunu takip eden Adana, İzmir ve Ankara’nın skorları birbirlerine çok yakındır; Hakkari ise $-6,07$ 'lik negatif skor ile son sırada yer almıştır. ${ }^{6}$ 


\section{İnsani Gelişmişlik Endeksi}

Faktör skorlarını birer birer incelemek yerine tüm faktörlerin etkilerini eşanlı olarak analiz ederek illerin nihai kalkınmışlık düzeylerini doğru bir şekilde belirleyebiliriz. Bu amaçla bu bölümde her bir faktörün toplam varyansı açıklamadaki payları dikkate alınarak iller için gelişmişlik endeksleri oluşturulmuştur. Herbir il $(i=1, \ldots, 81)$ için gelişmişlik endeksi aşağıdaki formül uygulanarak elde edilmiştir:

$$
\text { endeks }_{i}=\frac{\sum_{k=1}^{m=10} \text { Faktör_skoru }_{i k} \times \text { faktör_özdeğeri }_{k}}{\sum_{k=1}^{m=10} \text { faktör_özdeğeri }_{k}}=\frac{\sum_{k=1}^{m=10} F_{i k} \times \lambda_{k}}{\sum_{k=1}^{m=10} \lambda_{k}}
$$

burada, endeks değeri ilin faktör skorları ( ) ile sabit faktör özdeğerlerinin () çarpımının faktör özdeğerleri toplamına oranı alınarak elde edilmiştir. $\mathrm{Bu}$ endeks her bir il için oluşturulduktan sonra iller arasında sıralama yapılması için düzenlenmiş indeks aşağıdaki denklemde verildiği üzere oluşturulmuştur:

$$
\text { Düzenlenmiş endeks } s_{i}=\frac{\text { endeks }_{i}-\operatorname{Min}\left(\text { endeks }_{i}\right)}{\max \left(\text { endeks }_{i}\right)-\operatorname{Min}\left(\text { endeks }_{i}\right)} .
$$

Düzenlenmiş endeks değeri, ilin endeks değerinden minimum endeks değerinin çıkarılıp bunun maksimum ve minimum endeks farklarına oranlanmasıyla elde edilmiştir.

İller için düzenlenmiş gelişmişlik endeksi değerleri Tablo 4’te verilmiştir. Elde ettiğimiz sonuçlara göre maksimum endeks değerine sahip olan İstanbul'un düzenlenmiş endeks değeri 1'dir ve minimum endeks değerine sahip Muş'un düzenlenmiş endeks değeri ise 0'dır. 
Tablo 4. IIllerin Gelişmişlik Endeksleri

\begin{tabular}{|c|c|c|c|c|c|c|c|}
\hline SIRA-iL & İNDEKS & SIRA-IL & İNDEKS & SIRA-IL & INDEKS & SIRA-IL & İNDEKS \\
\hline 1-İSTANBUL & 1,000 & 22-SAKARYA & 0,292 & 43-BILECIK & 0,244 & 64-TUNCELII & 0,156 \\
\hline 2-ANKARA & 0,532 & 23-BALIKESIR & 0,288 & 44-ÇORUM & 0,240 & 65-KiLis & 0,142 \\
\hline 3-IZMIR & 0,464 & 24-YALOVA & 0,285 & 45-ARTVIN & 0,237 & 66-KARS & 0,136 \\
\hline 4-ANTALYA & 0,424 & 25-KARABÜK & 0,283 & 46-ERZINCAN & 0,231 & 67-ARDAHAN & 0,131 \\
\hline 5-MUĞLA & 0,408 & 26-KIRKLARELI & 0,277 & 47-ORDU & 0,229 & 68-ADIYAMAN & 0,115 \\
\hline 6-BURSA & 0,393 & 27-BARTIN & 0,276 & 48-ÇANKIRI & 0,229 & 69-IĞDIR & 0,110 \\
\hline 7-DENIZLI & 0,375 & 28-DŪZCE & 0,273 & 49-MALATYA & 0,222 & 70-BINGÖL & 0,065 \\
\hline 8-TEKİRDAĞ & 0,343 & 29-MERSIN & 0,271 & 50-TOKAT & 0,220 & 71-DIYARBAKIR & 0,063 \\
\hline 9-AYDIN & 0,328 & 30-AMASYA & 0,267 & 51-AKSARAY & 0,219 & 72-BATMAN & 0,057 \\
\hline 10-EDIRNE & 0,325 & 31-KAYSERI & 0,264 & 52-ELAZIĞ & 0,219 & 73-MARDIN & 0,051 \\
\hline 11-ESKIŞEHIR & 0,319 & 32-KARAMAN & 0,264 & 53-HATAY & 0,218 & 74-HAKKARİ & 0,044 \\
\hline 12-BOLU & 0,318 & 33-ZONGULDAK & 0,262 & 54-GÜMÜŞHANE & 0,207 & 75-VAN & 0,040 \\
\hline 13-BURDUR & 0,317 & 34-SAMSUN & 0,259 & 55-OSMANIYE & 0,194 & 76-ŞANLIURFA & 0,033 \\
\hline 14-MANISA & 0,316 & 35-KASTAMONU & 0,259 & 56-NiĞDE & 0,187 & 77-AĞRI & 0,031 \\
\hline 15-KOCAEL I & 0,307 & 36-AFYON & 0,257 & 57-KAHRAMANMARAS & 0,185 & 78-SIIRT & 0,028 \\
\hline 16-TRABZON & 0,305 & 37-NEVŞEHIR & 0,257 & 58-KIRŞEHIR & 0,183 & 79-BİTLis & 0,026 \\
\hline 17-KONYA & 0,304 & 38-GIRESUN & 0,253 & 59-KIRIKKALE & 0,182 & 80-ŞIRNAK & 0,013 \\
\hline 18-ÇANAKKALE & 0,304 & 39-SINOP & 0,251 & 60-BAYBURT & 0,176 & 81-MUŞ & 0,000 \\
\hline 19-RİZE & 0,302 & 40-KÜTAHYA & 0,246 & 61-SIVAS & 0,174 & & \\
\hline 20-ISPARTA & 0,293 & 41-GAZIANTEP & 0,245 & 62-ERZURUM & 0,170 & & \\
\hline 21-USAK & 0,293 & 42-ADANA & 0,244 & 63-YOZGAT & 0,159 & & \\
\hline
\end{tabular}

Kaynak: Kendi hesaplamalarımız.

Gelişmişlik endeksinin belirlenmesinde her faktörün rolü farklıdır, bazıları majör rol oynarken bazıları minör rol oynamaktadır. Örneğin en yüksek varyans açıklama yüzdesine sahip 1. Faktör en önemli rolü oynamaktadır. Dolayısıyla, İstanbul'un 1. Faktörde diğer illerden en az 10 kat daha iyi performans göstermesi bu ili genel sıralamada birinciliğe yükselten önemli bir sebeptir.

\section{İllerin gelişmişlik gruplarına göre dağılımı}

Yatırımlarda Devlet Yardımları Hakkındaki Karar'a göre yürürlüğe giren teşvik sisteminin uygulanması açısından illerin sosyo-ekonomik gelişmişlik seviyeleri 6 kademe olarak belirlenmiştir (http://www.resmigazete.gov. tr/eskiler/2012/06/20120619-1.htm, Erişim: 7.4.2016). Bu çalışma sonuçlarına göre İstanbul tüm illerden ileri bir gelişmişlik düzeyindedir, en yakın takipçisi Ankara’nın gelişmişliğinden yaklaşık 2 kat daha ileri seviyededir. Bu durum histogramda net bir şekilde görülmektedir (bk. Şekil 1). 


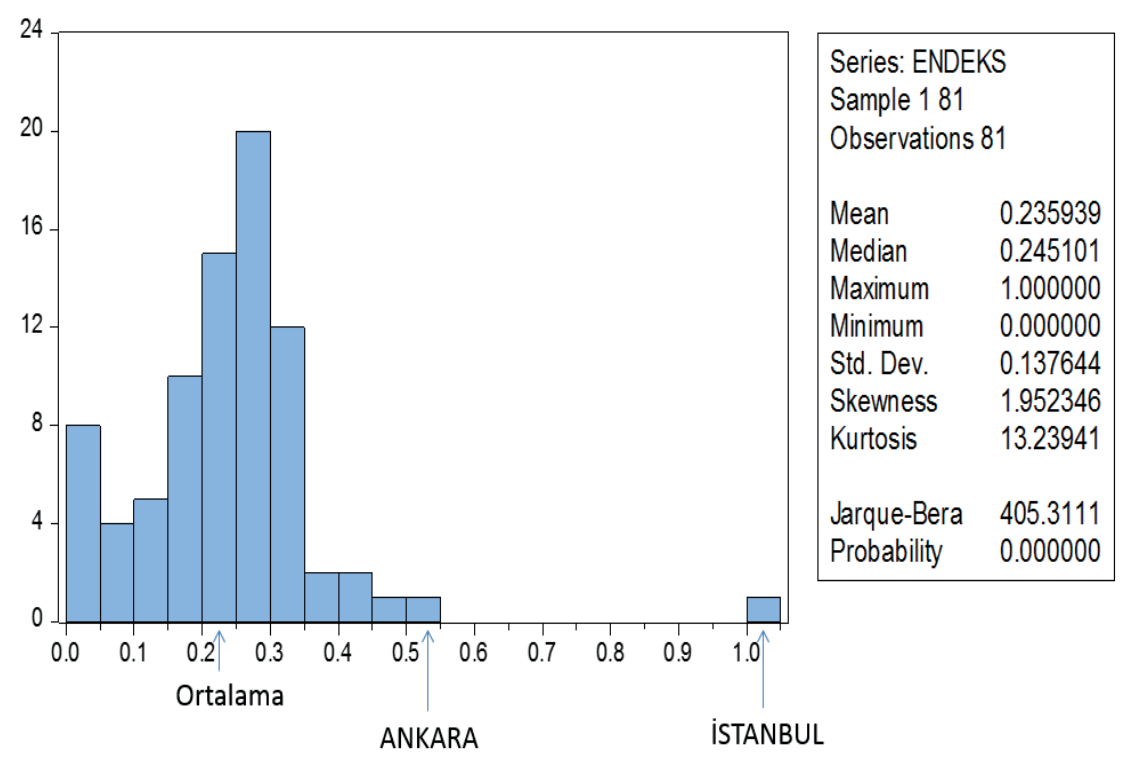

Şekil 1. İllerin gelişmişlik endeksleri: histogram

Şekil 1'de Tablo 4'te değerleri verilen illerin gelişmiş endekslerinin histogramı bulunmaktadır. Bu histogram illerin gelişmişlik durumunu görsel olarak daha rahat algılamamızı sağlamaktadır. Açıkça görüldüğü üzere İstanbul 1. Gelişmişlik düzeyini oluşturmaktadır ve bu düzey diğer tüm illerimizin çok ilerisindedir.

Geri kalan 2.-6. Gelişmişlik Düzeylerini oluşturmak için İstanbul bir uçdeğer kabul edilmiştir. İstanbul dışlanarak kalan 80 il için histogram yeniden çizildiğinde endeks değerlerinin -0.1479 çarpıklık (skewness) ve 3.145 kurtosis değerleri ile normal dağılıma uyduğu görülmektedir (JarqueBera $p$-değeri $0.8344>0.5$ ) (bk. Şekil 2). Ortalama gelişmişlik endeksi değeri 0,2263'tür ve Tablo 4’te görüldüğü üzere Çankırı ve Malatya illerinin arasında yer almaktadır. Endeksin medyan (ortanca) değeri ise 0,2444 'tür ve Gaziantep, Adana ve Bilecik bu değer etrafında değer almaktadır. 


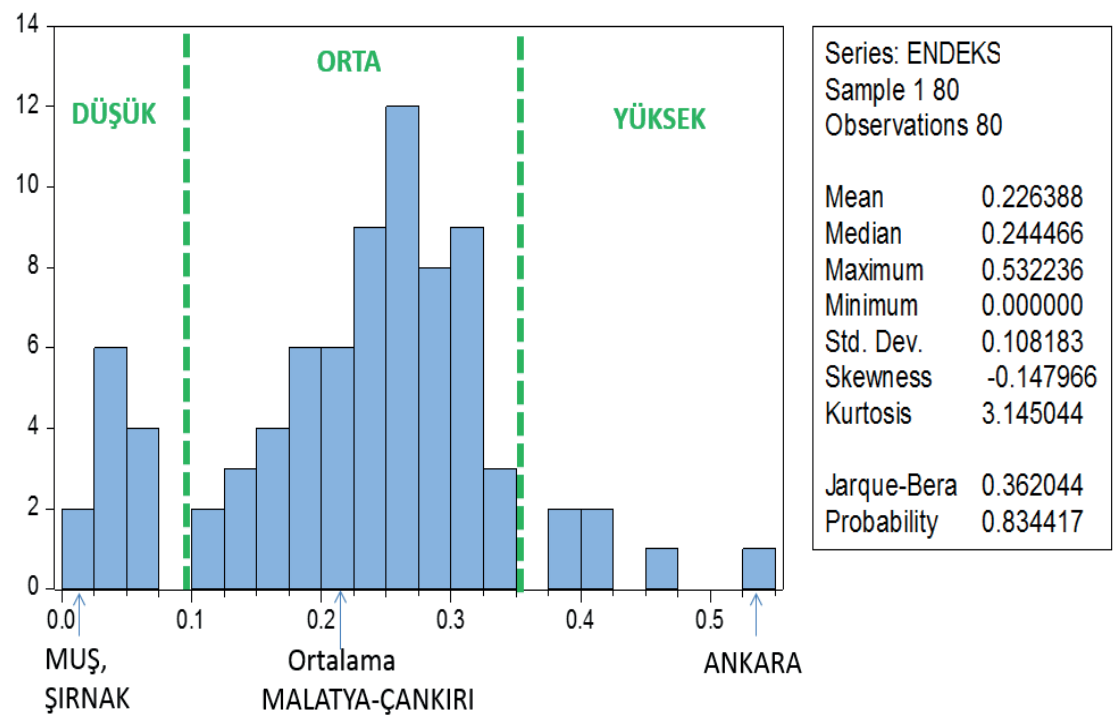

Şekil 2. Illerin gelişmişlik endeksleri: histogram-İstanbul hariç

Şekil 2'de illerin gelişmişlik endeks değerlerinin 3 temel seviyede öbeklendiği görülmektedir, bunlar: Gelişmişlik endeksi 0,35 'ten yüksek olan bir grup il, endeksleri 0,10'dan düşük olan bir grup il ve bunlarına ortasında kalan orta performans gösteren iller. Kendiliğinden oluşan bu kesim değerleri bize 2.seviyede gelişmiş illerin endeks değerlerinin en az 0,35 olduğu bilgisini vermektedir. En düşük seviye olan 6 . Seviyedeki illerin ise endeks değerleri 0,10'dan düşük olacaktır.

Şekil 1 ve 2'den elde edilen bilgiler altında illerin gelişmişlik gruplarına göre dağılımı Tablo 5 'te verilmiştir. Buna göre endeks değerleri 0,10'dan az olan iller 6. kademe gelişmişlik seviyesindedir ki bu kademe "düşük" gelişmişlik grubunu oluşturmaktadır. Gelişmişlik endeksi 0,35 ile 0,10 arasında olan iller "orta" gelişmişlik grubunu oluşturmaktadır. Orta gelişmişlik grubu da "düşüğe yakın", "ortalamaya yakın" ve "yükseğe yakın" olmak üzere üç seviyede değerlendirilmiştir. Endeks değerlerinin dağılımı normal olduğu için orta düzey gelişmişliği üç bölüme ayırırken $0,10-0,35$ aralığının genişliği üçe bölünerek her bir alt aralık için eşit genişlik belirlenmiştir ((0,35$0,10) / 3=0.0833)$. Buna göre endeks değerleri $[0.10,0.1833)$ aralığında olan iller düşüğe yakın, $[0.1833,0.2666)$ aralığında olan iller ortalamaya yakın ve $[0.2666,0.35)$ aralığındaki iller yükseğe yakın gelişmişlik grubundadır ve bu aralıklar sırasıyla 5., 4. ve 3. kademe gelişmişlik seviyelerini oluşturmaktadır. 
Tablo 5. İllerin Gelişmişlik Gruplarına Göre Dağılımı

\begin{tabular}{|c|c|c|c|c|c|c|}
\hline \multirow{2}{*}{$\begin{array}{l}\text { Geliş- } \\
\text { mişlik } \\
\text { Grubu }\end{array}$} & \multirow{2}{*}{ İleri } & \multirow[b]{2}{*}{ Yüksek } & \multicolumn{3}{|c|}{ Orta } & \multirow[b]{2}{*}{ Düşük } \\
\hline & & & Yükseğe Yakın & $\begin{array}{l}\text { Ortalamaya Ya- } \\
\text { kın }\end{array}$ & Düşüğe Yakın & \\
\hline $\begin{array}{l}\text { Geliş- } \\
\text { mişlik } \\
\text { Kade- } \\
\text { mesi } \\
\end{array}$ & 1 & 2 & 3 & 4 & 5 & 6 \\
\hline $\begin{array}{l}\text { Endeks } \\
\text { Değeri }\end{array}$ & $\begin{array}{c}\text { Endeks } \geq \\
0.6590\end{array}$ & $\begin{array}{c}0.6590>\text { En- } \\
\text { deks } \geq 0.35\end{array}$ & $\begin{array}{c}0.35> \\
\text { Endeks } \geq 0.2666\end{array}$ & $\begin{array}{c}0.2666> \\
\text { Endeks } \geq 0.1833 \\
\end{array}$ & $\begin{array}{c}0.1833> \\
\text { Endeks } \geq 0.10 \\
\end{array}$ & $0.10>$ Endeks \\
\hline \multirow{27}{*}{ İLLER } & \multirow[t]{27}{*}{ İSTANBUL } & ANKARA & TEKİRDAĞ & KAYSERİ & KIRŞEHİR & BİNGÖL \\
\hline & & İZMİR & AYDIN & KARAMAN & KIRIKKALE & $\begin{array}{l}\text { DİYARBA- } \\
\text { KIR }\end{array}$ \\
\hline & & ANTALYA & EDİRNE & ZONGULDAK & BAYBURT & BATMAN \\
\hline & & MUĞLA & ESKİŞEHİR & SAMSUN & SIVAS & MARDIN \\
\hline & & BURSA & BOLU & KASTAMONU & ERZURUM & HAKKARİ \\
\hline & & DENİZLI & BURDUR & AFYON & YOZGAT & VAN \\
\hline & & & MANİSA & NEVŞEHİR & TUNCELİ & ŞANLIURFA \\
\hline & & & KOCAELİ & GİRESUN & KİLIS & AĞRI \\
\hline & & & TRABZON & SİNOP & KARS & Sİ̈T \\
\hline & & & KONYA & KÜTAHYA & ARDAHAN & BİTLİS \\
\hline & & & ÇANAKKALE & GAZİANTEP & ADIYAMAN & ŞIRNAK \\
\hline & & & RİZE & ADANA & IĞDIR & MUŞ \\
\hline & & & ISPARTA & BİLECİK & & \\
\hline & & & UŞAK & ÇORUM & & \\
\hline & & & SAKARYA & ARTVIN & & \\
\hline & & & BALIKESİR & ERZINNCAN & & \\
\hline & & & YALOVA & ORDU & & \\
\hline & & & KARABÜK & ÇANKIRI & & \\
\hline & & & KIRKLARELİ & MALATYA & & \\
\hline & & & BARTIN & TOKAT & & \\
\hline & & & DÜZCE & AKSARAY & & \\
\hline & & & MERSİN & ELAZIĞ & & \\
\hline & & & AMASYA & HATAY & & \\
\hline & & & & GÜMÜŞHANE & & \\
\hline & & & & OSMANIYE & & \\
\hline & & & & NİĞDE & & \\
\hline & & & & $\begin{array}{l}\text { KAHRAMAN- } \\
\text { MARAŞ }\end{array}$ & & \\
\hline
\end{tabular}


$\mathrm{Bu}$ şekilde 3.-6. kademe gelişmişlik sınırları belirlenmiştir. 2.Kademe gelişmişlik düzeyinin yani "yüksek" gelişmişlik grubunun alt sınırı $(0,35)$ kendiliğinden oluşmuştur. Şimdi, 2. Kademe yüksek gelişmişlik ile 1. Kademe ileri gelişmişlik gruplarının sınırını belirlemek gerekmektedir. Şekil 4 te görüldüğü üzere, Yüksek gelişmişlik grubuna dahil en yüksek endeksli il 0.532 endeks puanı ile Ankara’dır ve en düşük endeksli il 0.375 puan ile Denizli'dir. Ankara ortalama endeks değerinin yaklaşık $3 \sigma$ uzağında yer almaktadır $(\mu+3 \sigma=0.2263+3(0.108183)=0.5508)$. Bir uç eğer olan ve tek başına 1. Kademe "ileri” gelişmişlik grubunu oluşturan İstanbul'un endeksi ortalamanın $7 \sigma-8 \sigma$ uzağında yer almaktadır. Bu durumda 2.kademe ve 1.kademe arasındaki kesim değeri $\mu+4 \sigma=0.6590(=0.2263+4(0.108183))$ olarak belirlenmiştir. Endeks değerleri $[0.35,0.6590)$ aralığında olan iller 2.gelişmişlik kademsindedir ve yüksek gelişmişlik grubunu oluşturmaktadır. Endeks değerleri en az 0,6590 olan iller ise 1. kademe gelişmişlik seviyesindedir ve ileri gelişmişlik grubunu oluşturmaktadır.

Tablo 5'te görüldüğü üzere sadece İstanbul 1.Kademe gelişmişlik seviyesindedir. Bu durumda 81 ilden 51’i (yani \%62,96’sı) 4. - 6. gelişmişlik seviyesindedir, 30'u ise (yani \%37,07'si) 1.-3. gelişmişlik kademelerinde yer almaktadır. Ortalama performans gösteren iller 4 . kademede yer almaktadır.

\section{Bölgelerin gelişmişlik düzeyi}

Bölgelerin gelişmişlik düzeyleri analiz edilirken hem 7 coğrafi bölge hem de NUTS-1 sınıflandırmasında göre oluşan 12 bölge eşanlı değerlendirilmiştir. NUTS-1 istatistiki bölge birimleri, coğrafi bölgelerin daha detaylandırılmış halidir. NUTS-1 sınıflandırması ile coğrafi bölge sınıflandırmaları birbirlerini çoğunlukla tutmaktadır. Aralarında sadece 5 sınır ili (Çankırı, Bayburt, Eskişehir, Düzce ve Bolu) için farklılık vardır. Güneydoğu Anadolu, Ege ve Akdeniz bölgelerindeki iller iki tanım alında da aynıdır. Marmara Bölgesi, NUTS-1'e göre İstanbul, Batı Marmara ve Doğu Marmara olmak üzere üçe ayrılmıştır. Dolayısıyla, İstanbul ili NUTS-1'e göre ayrı bir bölgeyi oluşturmaktadır.

Tablo 6'da illerin gelişmişlik kademlerinden faydalanılarak bölgelerin ortalama gelişmişlik kademleri hesaplanmıştır. 
Tablo 6. Bölgelere Göre Gelişmişlik

\begin{tabular}{|c|c|c|c|c|c|c|c|c|c|}
\hline & & \multicolumn{5}{|c|}{ ISTATISTIKI BÖLGE BIRIMLERI SINIFLANDIRMASI (IBBS) } & \multirow{3}{*}{$\begin{array}{l}\text { Illerin Geligmislilik } \\
\text { Kademesi }\end{array}$} & \multirow{3}{*}{$\begin{array}{l}\text { İllerin Nüfus } \\
\text { Yüzdesi }\end{array}$} & \multirow{3}{*}{$\begin{array}{c}\text { Ortalama } \\
\text { Geligmislik } \\
\text { NUTS1'e göre }\end{array}$} \\
\hline \multirow{2}{*}{$\begin{array}{l}\text { Coğrafifi Bölge } \\
\text { Simffandirması }\end{array}$} & \multirow{2}{*}{ Kod } & \multirow{2}{*}{$\begin{array}{l}\text { DUZZEY } 1 \text { (12 Bölge Birimi NUTS-1) } \\
\text { Tanım }\end{array}$} & \multicolumn{2}{|c|}{ DÜZEY 2 (26 Bölge Birimi) } & \multicolumn{2}{|c|}{ DÜZEY 3 (81 İ Düzeyinde) } & & & \\
\hline & & & Kod & Tanm & Kod & Tanm & & & \\
\hline \multirow{15}{*}{ 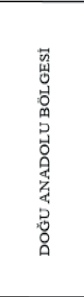 } & TRA & KUZEYDOĞU ANADOLU & TRA1 & ERZURUM & TRA11 & ERZURUM & 5 & $0,95 \%$ & \\
\hline & & & & & TRA12 & ERZINCAN & 4 & $0,28 \%$ & \\
\hline & & & & & TRA13 & BAYBURT* & 5 & $0,11 \%$ & \\
\hline & & & TRA2 & AĞRI & TRA21 & AGRI & 6 & $0,68 \%$ & 5,15 \\
\hline & & & & & TRA22 & KARS & 5 & $0,36 \%$ & \\
\hline & & & & & TRA23 & IĞDIR & 5 & $0,24 \%$ & \\
\hline & & & & & IRA24 & ARDAHAN & 5 & $0,12 \%$ & \\
\hline & TRB & ORTADOĞU ANADOLU & TRB1 & MALATYA & TRB11 & MALATYA & 4 & $0,98 \%$ & \\
\hline & & & & & TRB12 & ELAZIĞ & 4 & $0,73 \%$ & \\
\hline & & & & & TRB13 & BINGÖL & 6 & $0,34 \%$ & \\
\hline & & & & & TRB14 & TUNCELI & 5 & $0,10 \%$ & 5,27 \\
\hline & & & TRB2 & VAN & TRB21 & VAN & 6 & $1,38 \%$ & 5,21 \\
\hline & & & & & TRB22 & MUS & 6 & $0,51 \%$ & \\
\hline & & & & & TRB23 & BITLIS & 6 & $0,43 \%$ & \\
\hline & & & & & IRB24 & HAKKARI & 6 & $0,34 \%$ & \\
\hline \multirow{9}{*}{ 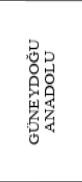 } & TRC & GÜNEYDOĞU ANADOLU & TRCl & GAZIANTEP & TRC11 & GAZIANTEP & 4 & $2,47 \%$ & \\
\hline & & & & & TRC12 & ADIYAMAN & 5 & $0,76 \%$ & \\
\hline & & & & & TRC13 & kilis & 5 & $0,16 \%$ & \\
\hline & & & TRC2 & ŞANLIURFA & TRC21 & SANLIURFA & 6 & $2,43 \%$ & \\
\hline & & & & & TRC22 & DIYARBAKIR & 6 & $2,10 \%$ & 5,45 \\
\hline & & & TRC3 & MARDIN & TRC31 & MARDIN & 6 & $1,00 \%$ & \\
\hline & & & & & TRC32 & BATMAN & 6 & $0,72 \%$ & \\
\hline & & & & & TRC33 & ȘRNAK & 6 & $0,61 \%$ & \\
\hline & & & & & TRC34 & SiliRT & 6 & $0,40 \%$ & \\
\hline \multirow{14}{*}{ 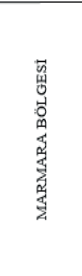 } & TR1 & ISTANBUL & TR10 & ISTANBUL & TR100 & ISTANBUL & 1 & $18,55 \%$ & 1,00 \\
\hline & TR2 & BATIMARMARA & TR21 & TEKIRDAG & TR211 & TEKIRDAG & 3 & $1,22 \%$ & \\
\hline & & & & & TR212 & EDIRNE & 3 & $0,50 \%$ & \\
\hline & & & & & TR213 & KIRKLARELI & 3 & $0,44 \%$ & 3,00 \\
\hline & & & TR22 & BALIKESIR & TR221 & BALIKESIR & 3 & $1,50 \%$ & \\
\hline & & & & & TR222 & CANAKKALE & 3 & $0.65 \%$ & \\
\hline & TR4 & DOĞU MARMARA & TR41 & BURSA & TR411 & BURSA & 2 & $3,64 \%$ & \\
\hline & & & & & TR412 & ESKISIEHEIIR* & 3 & $1,06 \%$ & \\
\hline & & & & & TR413 & BILECIK & 4 & $0,27 \%$ & \\
\hline & & & TR42 & KOCAELİ & TR421 & KOCAELII & 3 & $2,29 \%$ & \\
\hline & & & & & TR422 & SAKARYA & 3 & $1,22 \%$ & 2,65 \\
\hline & & & & & TR423 & DÜZCE ${ }^{*}$ & 3 & $0,46 \%$ & \\
\hline & & & & & TR424 & BOLU* & 3 & $0,38 \%$ & \\
\hline & & & & & TR425 & YALOVA & 3 & $0.30 \%$ & \\
\hline
\end{tabular}

Notlar: Coğrafi olarak Düzce ve Bolu, Batı Karadeniz'in Doğu Marmara ile sınır illeridir. Bu iller Karadeniz Bölgesinde yer almalarına rağmen NUTS-1'de Doğu Marmara Bölgesine dahil edilmişlerdir. Coğrafi olarak Doğu Karadeniz’in Doğu Anadolu ile sınır illerinden olan Bayburt, NUTS-1 sınıflandırmasında Kuzeydoğu Anadolu Bölgesine dahil edilmiştir. Batı Anadolu ile Doğu Marmara sınırında yer alan Eskişehir coğrafi olarak İç Anadolu bölgesindedir, ancak NUTS-1'e göre Doğu Marmara Bölgesi'nde yer almıştır.

İllerin nüfus yüzdesi ilin nüfusunun toplam ülke nüfusuna oranından elde edilmiştir (İlin nüfus yüzdesi==İlin nüfusu/Toplam ülke nüfusu*100). İllerin nüfus bilgileri Türkiye İstatistik Kurumu (TÜİK), Adrese Dayalı Nüfus Kayıt Sistemi 2016 verileridir. 
Tablo 6. (Devam ediyor) Bölgelere Göre Gelişmişlik

\begin{tabular}{|c|c|c|c|c|c|c|c|c|c|}
\hline \multirow[b]{2}{*}{$\begin{array}{l}\text { Coografif } \\
\text { Bôlge }\end{array}$} & \multicolumn{5}{|c|}{ ISTATISTIKI BOLGE BIRIMLERI SINIFLANDIRMASI (IBBS) } & $\begin{array}{l}\text { S) } \\
\text { Y } 3 \text { (81 Il Düzeyinde) }\end{array}$ & \multirow[b]{2}{*}{$\begin{array}{c}\text { Gelismisilik } \\
\text { Kademesi }\end{array}$} & \multirow[b]{2}{*}{$\begin{array}{l}\text { Illerin Nüfus } \\
\text { Yüzdesi }\end{array}$} & \multirow[b]{2}{*}{$\begin{array}{l}\text { Ortalama Gelismislik } \\
\text { NUTS1'e gôre }\end{array}$} \\
\hline & Kod & Tanm & Kod & Tanm & Kod & Tanm & & & \\
\hline \multirow{8}{*}{ 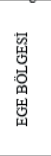 } & TR3 & EGE & TR31 & İMIR & TR310 & IZMIR & 2 & $5,29 \%$ & \multirow{8}{*}{2,53} \\
\hline & & & TR32 & AYDIN & TR321 & AYDIN & 3 & $1,34 \%$ & \\
\hline & & & & & TR322 & DENIZLI & 2 & $1,26 \%$ & \\
\hline & & & & & TR323 & MUĞLA & 2 & $1,16 \%$ & \\
\hline & & & TR33 & MANISA & TR331 & MANISA & 3 & $1,75 \%$ & \\
\hline & & & & & TR332 & AFYONKARAHISAR & 4 & $0,90 \%$ & \\
\hline & & & & & TR333 & KÜTAHYA & 4 & $0,72 \%$ & \\
\hline & & & & & TR334 & UȘAK & 3 & $0,45 \%$ & \\
\hline \multirow{11}{*}{ 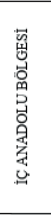 } & TR5 & BATI ANADOLU & TR51 & ANKARA & TR510 & ANKARA & 2 & $6,70 \%$ & \multirow{3}{*}{2,34} \\
\hline & & & TR52 & KONYA & TR521 & KONYA & 3 & $2,71 \%$ & \\
\hline & & & & & TR522 & KARAMAN & 4 & $0.31 \%$ & \\
\hline & \multirow[t]{8}{*}{ TR7 } & ORTA ANADOLU & TR71 & KIRIKKALE & TR711 & KIRIKKALE & 5 & $0,35 \%$ & \multirow{8}{*}{4,39} \\
\hline & & & & & TR712 & AKSARAY & 4 & $0,50 \%$ & \\
\hline & & & & & TR713 & NIĞDE & 4 & $0,44 \%$ & \\
\hline & & & & & TR714 & NEVŞEHIR & 4 & $0,36 \%$ & \\
\hline & & & & & TR715 & KIRȘEHIR & 5 & $0,29 \%$ & \\
\hline & & & TR72 & KAYSERI & TR721 & KAYSERÍ & 4 & $1,70 \%$ & \\
\hline & & & & & TR 722 & Sivas & 5 & $0,78 \%$ & \\
\hline & & & & & TR723 & YOZGAT & 5 & $0,53 \%$ & \\
\hline \multirow{8}{*}{ 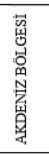 } & TR6 & AKDENIZ & TR61 & ANTALYA & TR611 & ANTALYA & 2 & $2,92 \%$ & \multirow{8}{*}{3,30} \\
\hline & & & & & TR612 & ISPARTA & 3 & $0,54 \%$ & \\
\hline & & & & & TR613 & BURDUR & 3 & $0,33 \%$ & \\
\hline & & & TR62 & ADANA & TR621 & ADANA & 4 & $2,76 \%$ & \\
\hline & & & & & TR622 & MERSIN & 3 & $2,22 \%$ & \\
\hline & & & TR63 & HATAY & TR631 & HATAY & 4 & $1,95 \%$ & \\
\hline & & & & & TR632 & KAHRAMANMARAS & 4 & $1,39 \%$ & \\
\hline & & & & & TR633 & OSMANIVE & 4 & $0,65 \%$ & \\
\hline \multirow{15}{*}{ 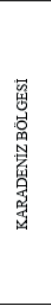 } & TR\& & BATI KARADENIZ & TR81 & ZONGULDAK & TR811 & ZONGULDAK & 4 & $0,75 \%$ & \multirow{10}{*}{3,83} \\
\hline & & & & & TR812 & KARABŪK & 3 & $0,30 \%$ & \\
\hline & & & & & TR813 & BARTIN & 3 & $0,24 \%$ & \\
\hline & & & TR82 & KASTAMONU & TR\&21 & KASTAMONU & 4 & $0,47 \%$ & \\
\hline & & & & & TR822 & CANKIRI* & 4 & $0,23 \%$ & \\
\hline & & & & & TR823 & SINOP & 4 & $0,26 \%$ & \\
\hline & & & TR83 & SAMSUN & TR831 & SAMSUN & 4 & $1,62 \%$ & \\
\hline & & & & & TR832 & TOKAT & 4 & $0,76 \%$ & \\
\hline & & & & & TR833 & ÇORUM & 4 & $0,66 \%$ & \\
\hline & & & & & TR834 & AMASYA & 3 & $0,41 \%$ & \\
\hline & TR9 & DOĞUKARADENIZ & TR90 & TRABZON & $\begin{array}{l}\text { TR901 } \\
\text { TR902 }\end{array}$ & $\begin{array}{l}\text { TRABZON } \\
\text { ORDU }\end{array}$ & $\begin{array}{l}3 \\
4\end{array}$ & $\begin{array}{l}0,98 \% \\
0,94 \%\end{array}$ & \multirow{5}{*}{3,58} \\
\hline & & & & & TR903 & GIRESUN & 4 & $0,56 \%$ & \\
\hline & & & & & TR904 & RIZE & 3 & $0,41 \%$ & \\
\hline & & & & & TR905 & ARTVIN & 4 & $0,21 \%$ & \\
\hline & & & & & TR906 & GÜMÜȘHANE & 4 & $0,22 \%$ & \\
\hline
\end{tabular}

Notlar: Çankırı, coğrafi olarak İç Anadolu bölgesinde iken, Batı Karadeniz ile Batı Anadolu arasındaki bu sınır ili NUTS-1'de Batı Karadeniz'e dahil edilmiştir.

NUTS-1 bölgelerinin nüfusa göre ağırlıklandırılmış ortalama gelişmişlik düzeyleri $\left(B G_{j}, j=1, \ldots, 12\right)$ aşağıdaki formüle göre hesaplanmıştır:

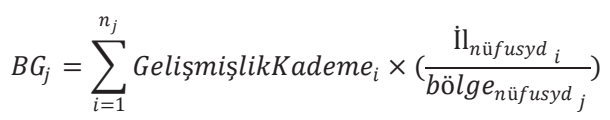

burada $n_{j}(j=1, \ldots, 12) \mathrm{j} . \quad$ bölgedeki il sayısıdır ve bölge $_{n \text { üfusyd }}{ }_{j}$ bölgedeki

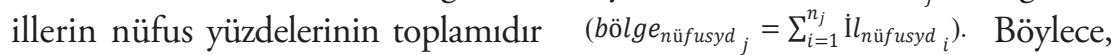
bölge-lerin gelişmişlik düzeyleri o bölgedeki illerin gelişmişlik düzeylerinin (Geliş̧işlikKademe $, i=1, \ldots, 81)$ ilin bölge nüfusundaki payı ile çarpılmasıyla elde edilmiştir. Bölgelerin gelişmişlik düzeyleri Tablo 7'de verilmiştir. 
Tablo 7. Bölgelerin Nüfusa Göre Ağırlıklandırılmıs Ortalama Gelişsmişlik Düzeyleri

\begin{tabular}{|c|c|c|c|c|}
\hline Kod & Bölge & $\begin{array}{l}\text { Ağırlıklandırılmış } \\
\text { Ortalama Gelişmişlik } \\
\text { Düzeyi }\left(B G_{j}\right)\end{array}$ & $\begin{array}{l}\text { Bölgenin Nüfus } \\
\text { Oranı }\left(b o ̈ l g e_{n u ̈ f u s y d} \text { ) }\right.\end{array}$ & $\begin{array}{l}\text { Türkiye'nin } \\
\text { Gelişmişlik } \\
\text { Düzeyi }\end{array}$ \\
\hline TR1 & İstanbul & 1,00 & $18,55 \%$ & \multirow{12}{*}{3,0734} \\
\hline TR5 & Batı Anadolu & 2,34 & $9,72 \%$ & \\
\hline TR3 & Ege & 2,53 & $12,87 \%$ & \\
\hline TR4 & Doğu Marmara & 2,65 & $9,62 \%$ & \\
\hline TR2 & Batı Marmara & 3,00 & $4,31 \%$ & \\
\hline TR6 & Akdeniz & 3,30 & $12,76 \%$ & \\
\hline TR9 & Doğu Karadeniz & 3,58 & $3,32 \%$ & \\
\hline TR8 & Batı Karadeniz & 3,83 & $5,70 \%$ & \\
\hline TR7 & Orta Anadolu & 4,39 & $4,95 \%$ & \\
\hline TRA & Kuzeydoğu Anadolu & 5,15 & $2,74 \%$ & \\
\hline TRB & Ortadoğu Anadolu & 5,27 & $4,81 \%$ & \\
\hline TRC & Güneydoğu Anadolu & 5,45 & $10,65 \%$ & \\
\hline
\end{tabular}

Tablo 7'de görüldüğü üzere nüfusa göre ağırlıklandırılmış ortalama gelişmişlik düzeyleri 3,50'dan düşük olan yani ortalamada yükseğe yakın performans gösteren bölgeler İstanbul, Batı Anadolu, Ege, Doğu Marmara, Batı Marmara ve Akdeniz bölgeleridir. Bu beş bölge toplam nüfusun $\% 67,83$ ünü kapsamaktadır. En ileri gelişmişlik düzeyinde (1. Düzey) olan bölge İstanbul'dur ve nüfusun \%18.55'i burada yaşamaktadır. Coğrafi olarak Marmara Bölgesini oluşturan İstanbul, Doğu Marmara ve Batı Marmara Bölgeleri diğer bölgelere göre yüksek performans göstermişlerdir. Doğu Marmara’da Bursa 2. Kademe gelişmişlik seviyesindeki tek ildir ve nüfusun \% 3,64'ünü kapsamaktadır. Bursa, üretim faktöründe Kocaeli’nden sonra ikinci sırada yer almaktadır (bk. Tablo 3). Coğrafi olarak İç Anadolu Bölgesini oluşturan Batı Anadolu ve Orta Anadolu bölgelerinin ortalama gelişmişlik düzeyleri ciddi farklılık göstermektedir. Orta Anadolu ortalama 4,39'luk bir düzeyde kalırken Batı Anadolu 2.34'lük ortalamasıyla hemen İstanbul'un ardında yer almıştır. Batı Anadolu bölgesinin en önemli avantajı nüfusun \%6.7'sini kapsayan ve 2. gelişmişlik kademesinde yer alan Ankara'dır. Ankara, sanayi ve banka mevduat hacmi faktörüne 2. sırada ve sağlık ve yükseköğretimde ilk sırada yer almaktadır (bk. Tablo 3).

Ege Bölgesi ortalamada 2,53'lük gelişmişlik düzeyi ile üçüncü sırada yer almaktadır. Bu bölge, yüksek ve yükseğe yakın gelişmişlik grubuna dahil 
birçok ili kapsamaktadır. Bunlardan İzmir 2. Gelişmişlik düzeyindedir ve nüfusun \%5,29'unu kapsamaktadır. İzmir, işletmecilik ile sağlık ve yüksek öğrenim faktörlerinde ilk beşte yer almaktadır (bk. Tablo 3). Akdeniz Bölgesi 3,30'luk ortalamasıyla gelişmişlikte Doğu Marmara ve Batı Marmara bölgelerinden sonra 6. sırada yer almaktadır. Bu bölgede dikkatleri üzerine çeken il Antalya’dır. Antalya bölgenin yüksek gelişmişlik grubuna dahil tek ilidir, işletmecilik faktöründe birinci sıradadır ve nüfusun \%2,92'sini içermektedir. Mersin ile Adana da nüfus yoğunlukları ve göreli iyi performansları ile bölgede öne çıkan illerdir.

Karadeniz Bölgesi, Doğu Karadeniz ve Batı Karadeniz, ile Orta Anadolu 3,58 ile 4,39 aralığındaki ortalamalarla vasat performans gösteren bölgelerdir. Doğu Karadeniz Bölgesine dikkat çeken husus Rize, Artvin, Gümüşhane, Giresun ve Trabzon'un istihdam faktörüne ilk beşte olmalıdır (bk. Tablo 3). Gümüşhane, Giresun ve Trabzon, TÜİK (2016) verilerine göre net göç alan iller olmuşlardır. Artvin ve Rize net göç veren iller olmasına rağmen gelişmemiş işgücü piyasaları nedeniyle düşük işsizlik oranına sahiptir.

Tablo 7 ve Tablo 8'de görüldüğü üzere en alt gelişmişlik seviyesinde olan bölgeler Doğu Anadolu (Kuzeydoğu Anadolu ile Ortadoğu Anadolu) ve Güneydoğu Anadolu Bölgeleridir. Bu bölgelerdeki dört il (Erzincan, Malatya, Elazığ ve Gaziantep) dışında tüm illerin gelişmişlik kademesi 5.-6. seviyelerdir. Bu bölgelerin nüfusu toplam nüfusun $\% 18.2$ 'sini $(=2,74 \%+4,81 \%+10,65 \%)$ oluşturmaktadır.

Doğu Anadolu ve Güneydoğu Anadolu Bölgelerinde sadece Erzincan, Malatya, Elazığ ve Gaziantep 4. gelişmişlik kademesinde bulunmaktadır. $\mathrm{Bu}$ bölgelerde en yüksek gelişmişlik düzeyini yakalayan il Gaziantep olmuştur (bk. Tablo 4). Gaziantep üretim faktöründe 3.sırada ve Kazanç faktöründe 1.sırada yer almıştır. Gaziantep, bölgesinde bir göç odağı haline geldiği için istihdam faktöründe düşük sırlarda yer almaktadır. Bu ilin sağlık ve yükseköğrenim, sanayi ve banka mevduat hacmi gibi diğer faktörlerdeki performansı düşüktür.

Tablo 7'de belirtildiği üzere Türkiye'nin nüfusa göre ağılıklandırılmış ortalama gelişmişlik düzeyi yaklaşık olarak 3'tür (tam olarak 3,0734=). Bu durumda Türkiye, ortalamada "Yükseğe yakın" gelişmişlik grubundadır. 


\section{Sonuç}

Çalışmamızda faktör analizi yöntemi kullanılarak Türkiye'deki illerin gelişmişliği tespit edilmiş ve birbirleri ile kıyaslayarak karşılaştırmalı olarak incelenmiştir. Devamında NUTS-1'e göre bölgelerin gelişmişlik düzeyleri tespit edilmiştir.

$\mathrm{Bu}$ analizler için illerin gelişmişlik düzeylerini etkileyen 58 değişken literatür takip edilerek seçilmiştir. Çalışmamızdaki veriler Dinçer (1996) ve Dinçer (2003) çalışmalarındaki veri setine benzer olmakla beraber bazı önemli farklılıklar vardır. Örneğin çalışmamızda yer alan, rekabetçi ve yenilikçi kapasite göstergeleri olarak değerlendirebileceğimiz marka ve patent başvuru sayıları, erişebilirlik göstergesi olan ve teknolojik gelişmelerin gündelik hayata önemli yansımaları olan GSM ve geniş bant aboneliği, internet bankacıllğına ait göstergeler, yaşam kalitesini etkileyen çevresel göstergeler Dinçer $(1996,2003)$ çalışmalarında yer almamaktadır. Bir onbeş-yirmi yıllık süreçte teknolojinin, sosyo-ekonomik koşulların ve duyarlılıkların geçirdiği değişimi göz önünde bulundurarak çalışmamızdaki veri seti 2016 yılı en güncel verilerinin Kalkınma Bakanlığı’ndan elde edilmesi ile gerçekleştirilmiştir.

Kalkınma Bakanlığı’nın (2013), 2011 yılı için SEGE çalışmasında yer alan 61 veri bizim verilerimize çok benzemektedir. Ancak SEGE_2011 çalışmasında güçlü temel bileşenler analizi uygulanmıştır. Dinçer (1996, 2003) çalışmalarında temel bileşenler analizi kullanılmıştır. Çalışmamızda ise faktör analizinde, faktörleri belirlemek için temel bileşenler yöntemi uygulanmıştır. Ayrıca, çalışmamızda 2012'de yürürlüğe giren yeni teşvik sistemine göre altı gruplu il kademeleri belirlenmiştir. Literatürdeki diğer çalışmalar (Dinçer 1996, Dinçer 2003, Gül ve Çevik 2015) illeri beş kademe altında tanımlamışlardır. Sadece Kalkınma Bakanlığı (2013) çalışmasında altı gruplu il kademeleri oluşturmuştur. Çalışmalar arasındaki veri seti ve yöntem farklılıklarını aklımızda tutarak, illerin ve bölgelerin gelişim süreci bulgularımızın literatürdeki diğer çalışmaların sonuçları ile karşılaştırılmasıyla değerlendirilecektir.

Bulgularımıza göre İstanbul 1. gelişmişlik düzeyini oluşturmaktadır ve bu düzey diğer tüm illerin çok ilerisindedir. Dinçer (2003) ve Kalkınma Bakanlığı (2013) çalışmalarında da İstanbul'un diğer illerin üstünde 
bir performans göstermiştir. Dinçer (2003) çalışmasında İstanbul'un gelişmişlik endeksi en yakın takipçisi Ankara’nın $1.45(=4.80772 / 3.31483)$ katı iken bu makas Kalkınma Bakanlığı (2013) çalışmasında biraz daha açılarak 1.59'a (=(4.5154/2.8384)) çıkmıştır (Dinçer 2003:. 55, Kalkınma Bakanlığı 2013: 50). Bu makas 2016'ya gelince daha fazla açılarak çalışmamız bulgularımıza göre 1.88 'e $(=1 / 0.532)$ yaklaşık 2 katına çıkmışıtır. Ayrıca şunun altını çizmemiz gerekir ki çalışmızda uçdeğerlerin etkisinin düşürmek için düzenlenmiş endeks değerleri kullanılmıştır. Dinçer (2003) ve Kalkınma Bakanlığı (2013)'teki gibi düzenlenmemiş endeks değerlerimizi kullandığımızda İstanbul-Ankara endeks oranı 2.58 'e çıkmaktadır. ${ }^{7}$

Şimdiye kadar yapılan çalışmalar İstanbul'u ayrı bir kategoride ve birinci seviye olarak tanımlamamıştır. Fakat analiz sonuçlarımız, literatürde de görülen İstanbul'un üstünlügünün son yıllarda çok daha da arttığını ortaya koymuştur. Bulgularımıza göre İstanbul'un aldığı yüksek gelişmişlik endeksi değeri bir uç değerdir. Bu durumda İstanbul'u ayrı bir kategoride incelemek yerindedir.

Ayrıca, faktör analizi bulgularımıza göre 1. faktör "Sanayi ve Banka Mevduat Hacmi” için skor sıralamaları incelendiğinde birinci sırada yer alan İstanbul'un skoru 8,49'tur ve onu takip eden Ankara'nın skoru sadece 0,82'dir. Bu durumda İstanbul en yakın takipçisinden 10 kat (=8.49/0.82) daha ileridir. Bu bulgumuz literatür ile paraleldir, zira İstanbul şehrin sanayi yapısının çeşitliliğinin doğurduğu bir kent ekonomisidir (Seyfeddinoğlu ve Ayoğlu 2007: 172, Dinçer 2003). Dinçer (2003)'te belirtildiği üzere bankacılık, finans faaliyetlerinin yoğunlaştığı dünya ölçeğinde ve bölgesel ölçekte hizmet veren kentler küresel kentlerdir ve Türkiye'de İstanbul bir küresel kenttir (Dinçer 2003: 57).

Aslında belli bir gelişmişlik seviyesi ve yukarısını yakalamış illerimiz için bu illerin potansiyellerinin tespit edilmesi ve potansiyelleri doğrultusunda kalkınma planlarının yapılması çok önemlidir. Bu durumda İstanbul'un potansiyeli nedir? İstanbul'un potansiyeli tespit edilmeli ve ilin nüfus, endüstri, finans ve tüm sosyo-ekonomik alanlarda daha ne kadarını yüklenebileceği doğru planlanmalıdır. TÜİK 2016 adrese dayalı nüfus kayıt sistemi verilerine göre 2015-2016 yılında İstanbul'un, verdiği göç aldığı göçten fazladır ve net göç vermektedir (http://www.tuik.gov.tr/ VeriBilgi.do?alt_id=1067, Erişim Tarihi: 25.05.2018). İstanbul'da tersine 
göç başlamıştır. Bu gösterge mühimdir, çünkü ilin net göç vermesi sadece nüfus potansiyeline ulaşmış olabileceği konusunda bir uyarı değildir aynı zamanda ilin istihdam, kazanç ve yaşam koşullarındaki potansiyelinin de değerlendirilmesi gerektiğini göstermektedir.

Yapılan analizimize göre İstanbul 1. kademe ileri düzey olarak belirlendikten sonra geri kalan 2.-6. gelişmişlik düzeyleri İstanbul bir uçdeğer kabul edilerek oluşturulmuştur. Bulgularımızda diğer illerin gelişmişlik endekslerinin kendiliğinden 3 grup altında öbeklendiği görülmüştür: Yüksek, Orta ve Düşük. Çalışmamızda yüksek gelişmişlikteki iller 2. kademeyi, orta seviyedeki iller 3., 4. ve 5. kademeleri ve düşük gelişmişlikteki iller 6.kademeyi oluşturmuştur.

Bulgularımıza göre 2. kademe gelişmişlik grubunu oluşturan ve "Yüksek" seviyede gelişmiş iller sırasıyla: Ankara, İzmir, Antalya, Muğla, Bursa ve Denizli'dir. Literatürdeki diğer çalışmalar İstanbul'u tek başına bir grup olarak değerlendirmedikleri için bizim 2. kadememizdeki iller Dinçer (2003) SEGE_2000 ve Kalkınma Bakanlığı (2013) SEGE_2011 çalışmalarındaki 1. kademedeki illere denk düşmektedir. İstanbul, Ankara, İzmir ve Bursa her iki SEGE çalışmasında da ilk grupta yer almaktadır. Ayrıca, Gül ve Çevik (2015), 2013 verileri ile illerin gelişmişlik endeksi çalışmasının sonuçlarına göre; 1 . grupta yer alan İstanbul ve diğer illerin (Ankara, İzmir, Antalya, Bursa ve Kocaeli'nin) en yüksek sosyo-ekonomik gelişmişlik seviyesine sahip iller olduğu ancak bu iller arasında da yüksek gelişmişlik farkının bulunduğunu belirtilmiştir. Turizm sektöründe önde olan Antalya ve Muğla, Kalkınma Bakanlığı (2013) çalışmasında da bir atılım yaparak 1. kademeye yükselmişti, bu iki il bulgularımıza göre başarılı performanslarını sürdürmektedir. Çalışmamızda diğer çalışma sonuçlarından farklı olarak Denizli'nin bir gelişme ivmesi ile yükseldiğini ve Kocaeli'nin sıralamada gerilediğini görmekteyiz.

Denizli ili gelişmişlik sıralamasında SEGE_2000 çalışmasında 11. sırada ve SEGE_2011 çalışmasında 10. sırada iken bu çalışmada özellikle üretim ve kazanç faktörlerindeki başarısı ile 7. sıraya yükselmiştir. Bulgularımız, kalkınmada öncelikli yöre politikaları kapsamında uygulanan teşviklerin Denizli'de etkili olduğu göstermektedir. Ayrıca gelecek yıllar için de Denizli'nin bu gelişme trendinin devamı beklenmektedir. Zira Ekonomi Bakanlığı'nın ilk kez 2017'de Denizli'de başlattığı ihracat seferliği ile 
Denizli'nin ihracatı Nisan 2018'de \% 23.5 artmıştır (http://www.dto.org. tr/ Erişim Tarihi: 28.05.2018).

Kocaeli ili ise SEGE 2000 ve 2011 çalışmalarında 4. sırada ve 1. gelişmişlik kademesinde iken bu çalışmada 15. sıraya gerilemiştir. Bulgularımızı incelediğimizde Kocaeli’nin üretim faktöründe ve GSM aboneliği faktörlerinde 1. olduğu görülmektedir. Ancak sağllk ve yüksek öğrenim ile kazanç faktörlerinde son sıralarda yer almıştır. Kazanç faktörü, içinde ortalama günlük kazancın da olduğu beş değişkenden oluşmaktadır. Üretim yüksek iken kazanç faktörünün düşük olması ilde katma değerin yüksek olduğu sektörlerde kayıtlı istihdamın yaygın olmadığını ve işgücü niteliğinin düşük olduğunu göstermektedir. Türkiye İş Kurumu Kocaeli Müdürü Ulvi Yılmaz’ın ve Kocaeli Sanayi Odası (KSO) Başkanı Ayhan Zeytinoğlu'nun Anadolu Ajans’a verdiği röportajda şu durumu belirtmişlerdir: İldeki istihdam çoğunlukla niteliksiz işgücünedir, meslek liseli nitelikli işgücüne talep düşüktür; niteliksiz işgücü ise işi ve ücretleri beğenmeme durumundadır. KSO Başkanı Ayhan Zeytinoğlu’nun belirttiği üzere Kocaeli'de 50 binin üzerinde kayıtlı işsiz olmasına rağmen firmaların işçi bulmada sıkıntı çekmektedir. İlde üretimde kapasite kullanım oranının yükselmesi durumda ise bu sorunlar daha da ciddi bir boyuta taşınacaktır (http://www.turkiyegazetesi.com.tr/ekonomi/434846.aspx, Erişim Tarihi: 29.05.2018). İşgücündeki bu yapısal sıkıntıların giderilmesi Kocaeli’nin gelişmesini sürdürebilmesi için gereklidir.

Çalışmamızda orta gelişmişlik grubu "yükseğe yakın”, "ortalamaya yakın” ve "düşüğe yakın” olmak üzere ve sırasıyla 3., 4. ve 5. gelişmişlik kademelerini oluşturmak üzere üç seviyede değerlendirilmiştir. Orta grupta olup yükseğe yakın performans gösteren iller arasında Tekirdağ, Edirne, Eskişehir, Kocaeli ve Kırklareli'nin de dahil olduğu 23 il bulunmaktadır. 3. kademe gelişmişlik gösteren bu grupta dikkat çeken Karadeniz illerinin gerçekleştirdikleri ilerlemelerdir. Bartın, SEGE_2000 ve SEGE_2011 çalışmalarında sırasıyla 51. ve 48. konumda iken bu çalışmada 27 . sıraya yükselmiştir. Bartın ilini özellikle kazanç ve istihdam faktörlerinde başarılıdır şöyle ki: Nüfus yoğunluğunun düşük olduğu bu ilimiz istihdam başına ücretin en yüksek olduğu illerdendir. ${ }^{8}$ Ayrıca, Kalkınma Bakanlığı (2016) raporunda da belirtildiği üzere imalat sanayi verimliği istihdam başına ciro olarak ölçüldüğünde Bartın ileri sıradadır (Kalkınma Bakanlığı 2016: 59). Trabzon 
ve Rize, SEGE_2011 çalışmasına göre 15'er sıra yükselerek bu çalışmamızda 16. ve 19. sıralarda yer almışlardır. Bu iller istihdam, üretim faktörü, sağlık ve yüksek öğrenim faktörlerindeki başarılarından dolayı sıra atlamıştır. Sonuçlarımıza benzer şekilde Gül ve Çevik'in (2015) 2013 yılı için illerin gelişmişlik sıralamasında Trabzon 16. ve finansal gelişmişlik sıralamasında 22. sırada bulunmaktadır. Trabzon bu gelişmesini sürdürürken Rize ili bir ivme ile yükselmiştir. Rize'de açılan devlet üniversitesi ve tıp fakültesi de ilin sosyo-ekonomik canlanmasına katkı sağlamaktadır (Sümer 2014). SEGE2011 çalışmasında Trabzon net göç veren bir il iken (Kalkınma Bakanlığı 2013: 61), TÜİK (2016) adrese dayalı nüfus kayıt sistemi verilerine göre 2015-2016 yılında Trabzon'nun aldığı göç verdiği göçten fazladır ve net göç almaktadır.

4. kademe ortalamaya yakın gelişmişlik grubunda 28 il yer almaktadır. Bu grupta en dikkat çeken il Adana'dır. Adana, gelişmişlik sıralamasında SEGE_2000 çalışmasında 8. sırada ve SEGE_2011 çalışmasında 16. sırada iken bu çalışmada 42. sıraya gerilemiştir. Adana, bulgularımıza göre istihdam ve sanayi faktörlerindeki düşük performansından dolayı bu sıradadır. SEGE_2011 çalışmasında bu ildeki işsizliğin sebebi göç alan bir ekonomi olmasıyla açıklanmışıı (Kalkınma Bakanlığı 2013: 82). Fakat, TÜİK (2016) verilerine göre 2015-2016 yılında Adana’nın verdiği göç aldığı göçten fazladır ve net göç hızı negatiftir. Türkiye'de sanayileşmenin gerçekleştiği ilk illerden olan Adana sanayisinde son yıllarda önemli bir gerileme gerçekleşmiştir. Adana’da son 10 yılda orta ve büyük ölçekli 55 fabrika kapanmıştır (http:// www.aljazeera.com.tr/al-jazeera-ozel/adanada-sanayi-geriliyor, Erişim Tarihi: 29.05.2018 ). 2015 yllında kapanan şirketlerin açılan şirketlere oranı Adana'da \%32 iken Türkiye'de \%27 olarak gerçekleşmiştir (Çukurova Kalkınma Ajansı 2017). Adana'da tarım ve tarıma dayalı sanayi ürünleri üretimi ve ihracatı şehrin ekonomisinde önemli bir yere sahiptir. Ancak il bu sektördeki potansiyelini etkin kullanamamaktadır ve bu sektörde de gerileme ve işsizlik ciddi bir problemdir (Çukurova Kalkınma Ajansı 2017). Çalışma bulgularımızın da ortaya koyduğu üzere Adana’nın gelişmesi için bu ile yatırımları teşvik eden politikalar uygulanmalıdır.

5. kademe "düşüğe yakın" ve 6 . kademe "düşük" gelişmişlik seviyelerinde 12 'şer ilimiz bulunmaktadır. Diğer SEGE çalışmalarında da aynı iller düşük performanslar göstererek son sıralarda yer almışlardır. 6. kademeyi Doğu ve 
Güneydoğu Anadolu bölgeleri illeri oluşmuştur ve bu illerin hepsi Kalkınma Bakanlığı (2013) SEGE_2011 çalışmasında da en düşük kategoride yer almışlardır. 5. kademedeki iller de çoğunlukla bu iki bölgelerdendir, ancak İç Anadolu bölgesinden de dört il bulunmaktadır: Kırşehir, Kırıkkale, Sivas ve Yozgat. Kırşehir ve Kırıkkale, SEGE_2011'de 40. ve 41. sıralarda yer alırken bulgularımıza göre 18 'şer sıra gerileyerek 58. ve 59. yer almışlardır. Bu iki il, Gül ve Çevik (2015) çalışmasına göre finansal gelişmişlikte oldukça düşük sırada yer almalarına karşın (Kırşehir 58., Kırıkkale 65.) finansal sektör için orta ve uzun vadede gelişme potansiyeline sahiptir. Kırıkkale’nin durumu özel bir durumdur, çekim merkezi Ankara’ya komşudur ve yoğun kamu yatırımı vardır. Fakat, bulgularımıza göre Dinçer (2003) çalışmasında da belirtilen kamu yatırımlarının yüksek olduğu illerde görülen sınai durgunluk ve gerilemenin hala etkisi altındadır. Sivas, SEGE_2011'de 49. sırada iken bulgularımıza göre istihdam, üretim ve işletme faktörlerinde düşük performans göstermiş ve 12 sıra gerileyerek 61. sırada yer almıştır. TÜİK (2016) verilerine göre Sivas ve Kırıkkale net göç veren iller olmuştur.

Çalışmamızda illerin gelişmişlik düzeylerinden sonra NUTS-1 sınıflandırmasında göre bölgelerin gelişmişlik düzeyleri analiz edilmiştir. Bulgularımız Dinçer (2003) SEGE_2000 bulgularıyla karşılaştırıldığında görülmüştür ki aslında 15 yıllık süreçte bölgelerin performanslarında önemli bir değişiklik olmamıştır. İstanbul ilk sırada, Doğu ve Güneydoğu Anadolu Bölgeleri en son sıralarda yer almaktadır. Sadece, Doğu Karadeniz Bölgesi, Dinçer (2003) çalışmasına göre bulgularımızda iki sıra yükselmiştir ve Doğu Marmara bir sıra gerilemiştir, diğer bölgelerin sıralamaları değişmemiştir.

Literatürdeki tüm çalışmalarda "Yüksek" kademesinde mutlaka İstanbul, Ankara ve İzmir yer almıştır ve bu illerin gelişmişlik endeksi diğer illerden çok daha yüksektir. Ancak bulgularımıza göre son yıllarda İstanbul makası açmıştır ve tek başına ileri kategorisini oluşturmuştur. Çalışmamızda düşük gelişmişlik grubuna giren iller Güneydoğu ve Doğu Anadolu bölgesi illeridir ve bunlar diğer çalışmalarda da sıklıkla aynı iller olmuştur.

Analizimiz bulgularına göre Türkiye'de yüksek ve düşük performanslı iller ve bölgeler kendiliğinden sivrilmektedir; fakat orta performans gösteren iller birbirlerine çok yakın performans göstermektedir. $\mathrm{Bu}$ sebepten aslında Türkiye'de altı gelişmişlik kademesi yerine kendiliğinden oluşan üç gelişmişlik kademesi vardır: Yüksek, orta ve düşük kademeler. Bu noktada 
ülkemizde uygulanan altı kademeli teşvik sistemi uygulaması yeniden gözden geçirilerek düşük ve orta gelişmişlik gösteren illerin ve bölgelerin yüksek performans gösteren illerin ve bölgelerin seviyesine yakınsamasını sağlanmalıdır.

Literatürdeki diğer çalışmalar Türkiye için bir ortalama gelişmişlik düzeyi hesaplanmamıştır. Bu analizi ilk kez çalışmamız gerçekleştirmiştir. Bulgularımıza göre Türkiye’nin nüfusa göre ağırlıklandırılmış ortalama gelişmişlik düzeyi yaklaşık olarak 3'tür. Bu durumda Türkiye, ortalamada "Yükseğe yakın" gelişmişlik grubundadır. Fakat yine bulgularımıza göre 81 ilden 51'i (yani \%62,96'sı) 4. - 6. gelişmişlik seviyesindedir, 30'u ise (yani \%37,07'si) 1.-3. gelişmişlik kademelerinde yer almaktadır. Bu durumda illerin \%63'ünün 4. - 6. gelişmişlik seviyesinde yer almalarına rağmen Türkiye'nin gelişmişlik seviyesinin 3. kademe çıkması ülkenin geneline yayılan bir kalkınmanın göstergesi değildir. Ancak bunun sebebi yüksek gelişmişlik seviyelerinde olan bölgelerin yoğun nüfus bulundurmalıdır. Zira ortalama gelişmişlik düzeyleri yüksek olan bölgeler toplam nüfusun \%67,83'ünü kapsamaktadır. İleri gelişmişlik düzeyinde (1. Düzey) olan tek bölge İstanbul'da en yoğun nüfus bulunmaktadır; nüfusun \%18.55'i bu bölgede yaşamaktadır. Yüksek gelişmişlik düzeyinde olan iller ve bölgeler cazibe merkezidir ve yüksek nüfusu barındırmaktadır. Ancak bunların temel sorunu istihdamdır.

Türkiye'de bölgesel kalkınmanın her yıl sürekli olarak incelenmesi gereklidir ve uygulanan kalkınma politikaların etkinliği takip edilmelidir. Dolayısıyla bölgesel kalkınma sürekli araştırılması gereken bir alan olarak araştırmacıların önünde durmaktadır.

\section{Açıklamalar}

1 Korelasyon matrisi $58 \times 58^{\prime}$ lik kare matristir, toplam 3364 değerden oluşmaktadır. Çok yer tutacağı için metinde verilememiştir. Matriste, korelasyonu 0,50 'den yüksek olan 350 değişken çifti ve $-0,50$ 'den küçük olan 66 değişken çifti bulunmaktadır.

2 KMO ölçütü kısmi korelasyon katsayıları ile gözlemlenen korelasyon değerlerini karşılaştıran bir indekstir. Barlett testi ise değişkenlerin arsında korelasyon olup olmadığını inceler. Boş hipotezinin ret edilmesi değişkenler arasında önemli bir ilişkinin varlığını belirtir.

3 Doğrusal rotasyon faktörleri birbirinden bağımsız olarak döndürmeyi ifade 
eder. Döndürmeden önce tüm faktörler bağımsızdır ve döndürmeden sonra eksenler birbirine dik olur (Tatlıdil 2002, Johnson ve Wichern 2007). Equamax yöntemi ile rotasyon uygulanarak dönüştürülmüş yük matrisi elde Ek Tablo 2'de verilmiştir.

4 Belli bir faktöre yükleme yapan değişkenlerin hepsinde ortak nokta her zaman olmayabilir. Bu durum, faktör analizinin bir dezavantajı olarak kabul edilebilir. Örneğin 8.Faktör "Kazanç" olarak adlandırılmıştır, fakat 8.Faktöre yükleme yapan önemli değişkenler V4 (İmalat Sanayi İstihdamının Sigortalı İstihdam İçinde Oranı), V6 (Ortalama Günlük Kazanç), V7 (Ortalama Günlük Kazanç- Kadın), V12 (İmalat Sanayi Kayıtlı İşyeri Oranı) ve V44 “Eczane Sayısı"dır. Burada V44 ildeki eczane sayısının 8.faktöre ismini veren kazanç ile doğrudan ilişkisi yoktur ancak dolaylı ilişkisi olabilir.

5 Tablo 3'te yer tutmaması için ilk 5 ve son 5 il verilmiştir, her bir faktör altında tüm illerin tam sıralaması ilgili okuyucuların yazarlardan istenmesi halinde temin edilecektir.

6 Çevre faktörünü dikkatli değerlendirmemiz gerekir, şöyle ki V54 Kükürtdioksit Ortalama Değeri ve V55 Partiküler Madde (Duman) Ortalama Değeri değişkenleri bu faktör ile yüksek negatif ilişki içindelerdir (bk. Ek Tablo 2)

7 Çalışmamızda aykırı değerlerin etkisini belli ölçüde düşürmek için düzenlenmiş endeksler ile çalışmayı tercih ettik. Ayrıca düzenlenmemiş endeksler pozitif ve negatif alabilmektedir ve ortalamada bu değerler birbirlerini götürdüğünde ortalama gelişmişlik endeksi sıfıra çok yakın çıkmaktadır.

8 Şunu belirtmemiz gerekir ki nüfus yoğunluğu faktör analizimizdeki 58 değişkenden biridir ve gelişmişlik endeks değerleri nüfus yoğunluğu değişkenin de yöntem tarafından değerlendirilmesi ile edilmiştir. Dolayısı ile illerin gelişmişlik kademlerini belirlerken diğer çalışmaların yaptığı gibi nüfus yoğunluğunu bir kez daha dişsal olarak değerlendirmedik. 3. Bölümde açıklanan istatistiki yöntemlerle kademeleri belirledik.

\section{Kaynaklar}

Atan, Murat, Ebru Özgür ve Hüseyin Güler (2004). "Çok değişkenli İstatistiksel Analizler ve VZA ile İllerin Gelişmişlik Düzeylerinin Karşılaştırılması”. Gazi Üniversitesi İktisadi ve İdari Bilimler Fakültesi Dergisi 6 (2): 25-42.

Bartholomew, David John (1984). "The Foundations of Factor Analysis". Biometrika 71(2): 221-232.

Benko, Michal, Wolfgang Härdle \& Alois Kneip Benko (2009). "Common Functional Principal Components". The Annals of Statistics 37(1): 1-34. 
Chatfield, C. A. \& J. Collins (1980). Introduction to Multivariate Analysis. London and New York: Chapman \& Hall.

Cooper, John C. B. (1983). "Factor Analysis: An Overview". The American Statistician 37(2): 141-147.

Çaşkurlu, Eren (2014). “(İstihdamsız İyileşme) Sorununa Karşı Kamusal Politikalar ve Önemi: Türkiye Açısından Bir Değerlendirme”. Amme İdaresi Dergisi 47(2): 43-76.

Çukurova Kalkınma Ajansı (2017). "Adana Yatırım Destek ve Tanıtım Stratejisi 2017", http://www.cka.org.tr/dosyalar/Adana_Yatirim_Destek_Tanitim_ Stratejisi21.02.2017.pdf (Erişim Tarihi: 26.05.2018).

Dağ, Rıfat (2000). "Doğu ve Güneydoğu Bölgelerinin Gelişmesi Örneğinde Bölgesel Kalkınma Makro Politikaları”. TESEV Konferansı Ocak, http:// tesev.org.tr/wp-content/uploads/2015/10/Yoksulluk.pdf (Erişim Tarihi 27.04.2016).

Denizli Ticaret Odasi (2018) http://www.dto.org.tr/icerik/ detay $=2636 / 0 /$ den $\%$ C $4 \%$ B 0zl $\%$ C $4 \%$ B 0 - \% C 4\% B 0 hracati-235b\%C3\%BCy\%C3\%BCd\%C3\%BC.html (Erişim Tarihi: 28.05.2018).

Dinçer, Bülent, Metin Özaslan ve Erdoğan Satılmış (1996). İllerin Sosyo-Ekonomik Gelişmişlik Sıralaması Araştırması. Ankara: DPT-Bölgesel Gelişme ve Yapısal Uyum Genel Müdürlüğü (BGYUGM).

Dinçer, Bülent, Metin Özaslan ve Taner Kavasoğlu (2003). İllerin ve Bölgelerin Sosyo- Ekonomik Gelişmişlik Sıralaması Araştırması. Ankara: DPTBGYUGM.

Flury, Bernhard (1998). Common Principal Components and Related Multivariate Models. New York: John Wiley \& Sons Inc.

Fukuyama, Francis (2000). The End of History? Globalization and the Challenges of a New Century. Eds. Patrick O’Meara et al. Indiana: Indiana University Press.

Gül, Erhan ve Bora Çevik (2015). “2013 Verileriyle Türkiye’de İllerin Gelişmişlik Düzeyi Araştırması”. İş Bankası, İktisadi Araştırmalar Bölümü, https:// ekonomi.isbank.com.tr/UserFiles/pdf/ar_07_2015.pdf (Erişim Tarihi: 25.05.2018).

Johnson, Richard A. \& Dean W. Wichern (2007). Applied Multivariate Statistical Analysis. 6th eds. USA: Prentice Hall.

Kalkınma Bakanlığı (2013). İlerin ve Bölgelerin Sosyo-ekonomik Gelişmişlik Sıralaması Araştırması. SEGE (2011). Ankara: Kalkınma Bakanlığı, Bölgesel Gelişme ve Yapısal Uyum Genel Müdürlüğü.

Kalkınma Bakanlığı. www.kalkinma.gov.tr/Pages/EkonomikSosyalGöstergeler.aspx (Erişim Tarihi: 20.05.2016).

Karg1, Nihal (2009). "Bölgesel Kalkınma Yaklaşımlarındaki Gelişmeler ve AB Perspektifi Altında Türkiye’nin Bölgesel Politika Analizi”. International Journal of Economic and Administrative Studies 1(3) Summer:19-39. 
Nielsen, Lynge (2011). "Classifications of Countries Based on Their Level of Development: How it is Done and How it Could be Done". IMF Working Paper. February.

Nosoohi, Iman \& Ali Zeinal-Hamadani (2011). "Urban Planning with the aid of Factor Analysis Approach: the Case of Isfahan Municipality”. Theoretical and Empirical Researches in Urban Management 6(1): 56-69.

Öztürk, Ahmet (2009). Homojen ve Fonksiyonel Bölgelerin Tespiti ve Türkiye İçin İstatistiki Bölge Birimleri Önerisi. Planlama Uzmanlığ 1 Tezi. Ankara: Devlet Planlama Teşkilatı Müsteşarlığı Bölgesel Gelişme ve Yapısal Uyum Genel Müdürlüğü.

Resmi Gazete. http:/www.resmigazete.gov.tr/eskiler/2012/06/20120619-1.htm, Erişim Tarihi: 7.4.2016.

Seyfeddinoğlu, Ümit ve Damla Ayoğlu (2007). “Türk İmalat Sanayiinde İllere Göre Yerelleşme ve Kentleşme Ekonomilerinin Belirlenmesi”. bilig Türk Dünyası Sosyal Bilimler Dergisi 43: 169-192.

Sümer, Gülizar Çakır (2014). "Rize'de Kentleşme Süreci”. Ekonomik ve Sosyal Araştırmalar Dergisi 10(1): 163- 183.

Tatlıdil, Hüseyin (2002). Uygulamalı Çok Değişkenli İstatistiksel Analiz. Ankara: Akademi Matbaası.

Tipping, Michael E. and Christopher M. Bishop (1999). "Probabilistic Principal Component Analysis". Journal of the Royal Statistical Society. Series B (Statistical Methodology) 61(3): 611-622.

TODAİE (2009). Ulusal Kalkınma ve Yerel Yönetimler -1-. Ankara: Türkiye ve Orta Doğu Amme İdaresi Enstitüsü TODAİE Yay.

TÜİK (2016). http://www.tuik.gov.tr/VeriBilgi.do?alt_id=1067 (Erişim Tarihi: 25.05.2018).

Ünsal, Aydın ve Ebru Özgür (2004). "Bölgesel Gelişimde Faktör Analizi Yaklaşımı”. Gazi Üniversitesi İktisadi ve İdari Bilimler Fakültesi Dergisi 6(1): 1-15.

Varol, Çiğdem, N. Aydan Sat, Z. Aslı Gürel Üçer ve S. Bahar Yenigül (2017). "Metropoliten Alanlarda Çok-Merkezli Mekansal Gelişmelerin Sürdürülebilirlik Üzerinden Değerlendirilmesi: Avrupa Birliği’ndeki Uygulamalar". Türk Bilim Araştırma Vakfı (TÜBAV) Bilim 10(1): 61-74. 


\section{Ekler}

Ek Tablo 1. Betimleyici İstatistikler

\begin{tabular}{lllllllll}
\hline Değişken & Ortalama & S.Sapma & Değişken & Ortalama & S.Sapma & Değişken & Ortalama & S.Sapma \\
\hline V1 & 10,46 & 3,21 & V21 & 11266,87 & 7059,59 & V41 & 256,49 & 110,43 \\
\hline V2 & 49,41 & 6,2 & V22 & 1,23 & 4,31 & V42 & 10,93 & 2,63 \\
\hline V3 & 65,64 & 4,84 & V23 & 1,23 & 4,95 & V43 & 1,99 & 0,89 \\
\hline V4 & 26,72 & 12,63 & V24 & 1,23 & 4,56 & V44 & 2,82 & 0,9 \\
\hline V5 & 19,07 & 6,69 & V25 & 3532,58 & 3123,31 & V45 & 17,37 & 14,19 \\
\hline V6 & 32,6 & 4,77 & V26 & 58,38 & 27,35 & V46 & 58,09 & 26,35 \\
\hline V7 & 34,26 & 3,98 & V27 & 5,5 & 3,67 & V47 & 1,23 & 4,42 \\
\hline V8 & 44,33 & 6,48 & V28 & 1,72 & 2,68 & V48 & 0,16 & 0,05 \\
\hline V9 & 1,23 & 5,36 & V29 & 1,23 & 5,14 & V49 & 0,8 & 0,13 \\
\hline V10 & 620,64 & 994,31 & V30 & 116,28 & 283,73 & V50 & 37,12 & 48,26 \\
\hline V11 & 1,23 & 3,6 & V31 & 67,45 & 23,83 & V51 & 85,81 & 12,71 \\
\hline V12 & 13,86 & 3,72 & V32 & 40,5 & 14,98 & V52 & 0,45 & 0,14 \\
\hline V13 & 0,94 & 1,14 & V33 & $-5,3$ & 9,26 & V53 & 73,27 & 37,27 \\
\hline V14 & 1,23 & 6,55 & V34 & 63,79 & 13,92 & V54 & 25,62 & 26,56 \\
\hline V15 & 1,23 & 1,09 & V35 & 92,39 & 3,02 & V55 & 75,14 & 29,5 \\
\hline V16 & 1,23 & 4,21 & V36 & 87,59 & 4,85 & V56 & 5,46 & 3,72 \\
\hline V17 & 1,14 & 2,86 & V37 & 33,9 & 8,1 & V57 & 102,7 & 42,47 \\
\hline V18 & 40,93 & 40,17 & V38 & 31,49 & 11,96 & V58 & 4,33 & 1,72 \\
\hline V19 & 1,97 & 2,98 & V39 & 231,17 & 7,72 & & & \\
\hline V20 & 84,09 & 42,81 & V40 & 7,08 & 2,08 & & & \\
\hline Kayma & $K$ & & & & & & & \\
\hline
\end{tabular}

Kaynak: Kendi hesaplamalarımız. Not: S.Sapma: Standart Sapma 
Ek Tablo 2. Dönüştürülmüs Yük Matrisi

\begin{tabular}{|c|c|c|c|c|c|c|c|c|c|c|c|c|c|c|c|c|c|c|c|}
\hline 14 & 3 & 30 & $\sqrt{24}$ & 19 & Vil & 116 & $\sqrt{29}$ & 147 & 78 & $\sqrt{25}$ & 18 & V2 & $\mathrm{VI}$ & V38 & $\sqrt{32}$ & V31 & V5 & V45 & V52 \\
\hline & 0,916 & 0,598 & & 0,388 & & & & & & 0,539 & & & & & & & & $-0,047$ & 0,110 \\
\hline$-0,05:$ & 04 & 0 & 0 & & & & & & & & & & & & & & & & \\
\hline & & & & & & & & & & & & & & & & & & & \\
\hline & & & & & & & & & & & & & & & & & & & 0,26 \\
\hline & & & & & & & & & & & & & & & & & & & 0,27 \\
\hline & & & & & & & & & & & & & & & & & & & 0,300 \\
\hline & & & & & & & & & & & & & & & & & & & 0,37 \\
\hline$-0,093$ & 0,059 & 0000 & (01) & $.0,053$ & & oes & & & & 0,071 & & & & & & & & & 0,14 \\
\hline & & & & & & & & & & & & & & & & & & $-0,343$ & 0,35 \\
\hline 0,102 & & 0,698 & 0,127 & 0,095 & 0,133 & 0,127 & 0,141 & & & 0,211 & & 0,145 & $-0,192$ & $0,0,7$ & $-0,243$ & .0215 & & -0.237 & $0 x$ \\
\hline
\end{tabular}

\begin{tabular}{|c|c|c|c|c|c|c|c|c|c|c|c|c|c|c|c|c|c|c|c|c|}
\hline & $V_{42}$ & V210 & V4l & V4) & Vas & Vy4 & 170 & V19 & 128 & V15 & Vis & VSO & Vys & Vis & V27 & V46 & V21 & $\sqrt{136}$ & VS & VS \\
\hline & 0,040 & 0,339 & $.0,029$ & 0,118 & 0,109 & 0,174 & 0,253 & 0,228 & 0,223 & 0,134 & 0,138 & 0,328 & 0,010 & 0,288 & 0,350 & 0,099 & $.0,092$ & 0,033 & 0,030 & 0,118 \\
\hline & 0,141 & $0,0,04$ & 0,308 & 0,185 & 0,283 & $-0,353$ & $-0,040$ & 0,1 & $-0,012$ & $-0,176$ & 0,096 & $-0,078$ & $-0,068$ & 0,0 & 0,174 & $-0,185$ & $-0,015$ & 0,318 & 0,318 & 0,123 \\
\hline & 0,787 & 0,714 & 0,713 & 0,587 & 0,457 & 0,451 & 0,017 & 0,123 & 0,202 & 0,307 & 0,171 & 0,427 & 0,101 & 0,372 & 0,324 & 0,105 & 0,515 & 0,232 & 0,233 & 0,401 \\
\hline & 0,059 & 0,178 & $.0,094$ & 0,193 & 0,292 & 0,48 & 0,817 & 0,612 & 0.5 & 0,5 & 0,453 & 0,453 & 0,451 & 0,439 & 0,429 & 0,257 & 0,046 & 0,245 & 0,249 & 0,108 \\
\hline & 0,2023 & 0,285 & $.0,40$ & 0,336 & 0,332 & $0,2 \pi$ & 0,118 & 0,314 & 0,247 & 0,171 & 0,379 & 0,167 & 0,170 & 0,437 & 0,359 & 0,724 & 0,628 & 0,550 & 0,582 & 0.557 \\
\hline & 0,255 & 0,118 & 0,062 & 0,400 & 0,327 & 0,142 & 0,024 & 0,014 & 0,140 & $-0,211$ & 0,402 & 0,141 & 0,428 & 0,296 & 0,249 & 0,109 & 0,021 & 0,282 & 0,291 & 0,219 \\
\hline & 0,097 & 0,14 & $.0,205$ & 0,240 & 0,317 & $-0,073$ & 0,075 & 0,003 & 0,110 & 0,199 & 0,229 & 0,310 & 0,324 & 0,254 & 0,418 & 0,071 & 0,064 & 0,182 & 0,184 & 0,269 \\
\hline & 0,102 & 0,165 & 0,210 & 0,057 & 0,161 & 0,093 & $-0,076$ & 0,056 & $-0,357$ & 0,314 & 0,030 & 0,079 & 0,092 & $-0,131$ & 0,147 & 0,309 & 0,098 & 0,243 & 0,220 & 0,370 \\
\hline & 0,225 & 0,149 & 0,284 & 0,296 & 0,281 & 0,246 & 0,237 & 0,129 & 0,322 & $-0,062$ & 0,348 & 0,256 & 0,225 & 0,317 & 0,290 & 0,296 & 0,066 & 0,355 & 0,360 & 0,234 \\
\hline & 0,259 & 0,213 & 0,072 & 0,315 & 0,254 & 0,274 & 0,030 & 0,069 & 0,196 & 0,190 & 0,049 & 0,190 & 0,116 & $-0,009$ & 0,182 & 0,079 & 0,222 & 0,244 & 0,241 & 0,163 \\
\hline
\end{tabular}

\begin{tabular}{|c|c|c|c|c|c|c|c|c|c|c|c|c|c|c|c|c|c|}
\hline v57 & VSs & v37 & $v_{3}$ & V26 & v22 & V17 & V51 & 17 & 16 & $\mathrm{V12}$ & 14 & $V_{44}$ & 19 & V54 & V55 & v39 & v56 \\
\hline$-0,6 \times 6$ & $2,00 \%$ & $-0,019$ & 0,048 & 0,363 & 0,099 & 0.235 & 0,096 & 0,072 & 0,219 & 0,170 & $-0,027$ & 0,021 & 20,0 & $-0,48$ & $0,0,040$ & $-0,103$ & 0,078 \\
\hline 0,250 & 0,005 & $.0,108$ & 0,467 & 0.184 & 0,039 & 0,053 & $-0,04$ & $-0,0$ & & & 0.21 & & $-0,071$ & .0047 & 0,379 & $.0,071$ & $-0,257$ \\
\hline 0,157 & 0,121 & & 0,300 & 0.379 & & & & & & & & & $-0,042$ & & & & 0,118 \\
\hline 0,087 & $-0,186$ & 0,070 & 0,104 & 0,296 & $-0,0$ & & & & & & & & $-0,101$ & $0,0,07$ & 4 & 0,147 & $-0,210$ \\
\hline 0,502 & 0,000 & $-0,034$ & 0,364 & 0,365 & & & & $-0,0$. & $.0,0$ & & & & $-0,131$ & 0,107 & & 0,335 & 0,054 \\
\hline 0,330 & 0,770 & $0, ต 3$ & 0,513 & 0,432 & & & & & $.0,2$ & & & & $-0,183$ & $.0,004$ & 0,1 & 0,238 & 0,260 \\
\hline 0,152 & & & 0 & 332 & & & & & & 0,1 & -03 & & 0.125 & 131 & & 8 & \\
\hline 0,476 & 0,097 & 0,117 & 0,222 & $-0,074$ & 0,044 & 0,00 & & 48 & $-0,7$ & 0,5 & & & $\langle 0,02$ & $-0,148$ & 0,078 & 0,427 & $-0,287$ \\
\hline 0,004 & $-0,076$ & 0,148 & 0,320 & 0,285 & 0,165 & 0,188 & 0,126 & 0,053 & .0,098 & 0,185 & 0,236 & 0,176 & 0,874 & 0,056 & 0,201 & 0,140 & $.0,141$ \\
\hline 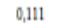 & 018 & 0,195 & 0.213 & 0.145 & 0,105 & 0.105 & 0,317 & 105 & 078 & 191 & 012 & 289 & & 8 & 0,787 & 493 & \\
\hline
\end{tabular}

Kaynak: Kendi hesaplamalarımız. 


\title{
Determination and Comparison of Development Levels' Across Regions: Turkey Case
}

\author{
Aydın Ünsal ${ }^{* *}$ \\ Seher Nur Sülkü ${ }^{* * *}$
}

\begin{abstract}
This study aims to compare and scrutinize development levels of cities and regions in Turkey. Socio-economic statics that effects development levels of cities acquired form Ministry of Development. Within the context of the essay, factor analysis relying to principles components utilized and as a result, 10 basic factors found. Based on these factors, development indexes developed for cities and six development stages defined: Advanced (1), High (2), Upper Intermediate(3), Average(4), Low(5), Very Low(6). İstanbul is the only city that reaches advanced level and its development index doubled Ankara, the second most developed city. Comparing development indexes of the regions, we classified Marmara, West Anatolia, Aegean and Mediterranean close to upper intermediate level. Low-level regions are East Anatolia and Southeast Anatolia regions. In overall Turkey with 3 levels of development could be included in upper intermediate level. Even though 63\% of all cities are between 4-6 developments levels the reason that Turkey's average appears as $3^{\text {rd }}$ level is mainly because high population concentrated in advanced and upper intermediate regions. Finally yet importantly, main problem of these highly developed regions is unemployment.
\end{abstract}

\section{Keywords}

Development, regional development level, principal components analysis, factor analysis, Turkey.

Date of Arrival: 20 September 2017 - Date of Acceptance: 30 May 2019

You can refer to this article as follows:

Ünsal, Aydın and Seher Nur Sülkü (2020). "Bölgeler Arası Gelişmişlik Düzeylerinin Belirlenmesi ve Karşılaştırılması: Türkiye Örneği”. bilig - Journal of Social Sciences of the Turkic World 95: 177-209.

** Prof. Dr., Ankara Hacı Bayram Veli University, Faculty of Economics and Administrative Sciences, Department of Econometrics - Ankara/Turkey

ORCID ID: 0000-0002-7922-1329

aydin.unsal@hbv.edu.tr

*** Prof. Dr., Ankara Hacı Bayram Veli University, Faculty of Economics and Administrative Sciences, Department of Econometrics - Ankara/Turkey

ORCID ID: 0000-0002-4938-4565

seher.sulku@hbv.edu.tr 


\title{
Определение и сравнение уровней развития по регионам: пример Турции
}

\author{
Айдын Уйсал ${ }^{* *}$ \\ Сехер Нур Сюлькю
}

\begin{abstract}
Аннотация
Данное исследование направлено на сравнение и тщательное изучение уровней развития городов и регионов Турции. Социально-экономическая статистика, влияющая на уровень развития городов, получена от Министерства развития. В контексте эссе был проведен факторный анализ, основанный на использованных основных компонентах, и в результате были найдены 10 базовых факторов. На их основе были разработаны индексы развития городов и определены шесть стадий развития: продвинутый (1), высокий (2), выше среднего (3), средний (4), низкий (5), очень низкий (6). Стамбул - единственный город, достигший продвинутого уровня, и его индекс вдвое больше индекса Анкары, второй наиболее развитый город. Сравнивая индексы развития регионов, мы отнесли регионы Мраморного моря, Западной Анатолии, Эгейского и Средиземноморского побережья к уровню выше среднего. Регионы низкого уровня - это регионы Восточной Анатолии и Юго-Восточной Анатолии. В целом Турция с 3 уровнями развития может быть отнесена к уровню выше среднего. Несмотря на то, что 63\% всех городов находятся между 4-6 уровнями развития, причина того, что средний показатель по Турции отображается как 3-й уровень, заключается в основном в том, что большая часть населения сконцентрирована в регионах с показателями «развитый» и «выше среднего уровня». Наконец, что немаловажно, главная проблема этих высокоразвитых регионов - безработица.

Ключевые слова

Развитие, уровень регионального развития, анализ основных компонентов, факторный анализ, Турция.
\end{abstract}

* Поступило в редакцию: 20 сентября 2017 г. - Принято в номер: 30 мая 2019 г.

Ссылка на статью:

Ünsal, Aydın and Seher Nur Sülkü (2020). "Bölgeler Arası Gelişmişlik Düzeylerinin Belirlenmesi ve Karşılaştırılması: Türkiye Örneği”. bilig - Журнал Гуманитарных Наук Тюркского Мира 95: 177-209.

** Проф., д-р, Университет Хаджи Байрама Вели, экономический факультет, кафедра эконометрики - Анкара / Турция ORCID ID: 0000-0002-7922-1329 aydin.unsal@hbv.edu.tr

*** Проф., д-р, Университет Хаджи Байрама Вели, экономический факультет, кафедра эконометрики - Анкара / Турция ORCID ID: 0000-0002- 4938-4565 seher.sulku@hbv.edu.tr 